\title{
Comprehensive analysis of proteolysis during 8 months of ripening of high-cooked Old Saare cheese
}

\author{
A. Taivosalo, ${ }^{*} \dagger^{1}$ T. Kriščiunaite, ${ }^{*}$ A. Seiman, ${ }^{*} \dagger$ N. Part, ${ }^{*}$ I. Stulova, ${ }^{*}$ and R. Vilu${ }^{*} \dagger$ \\ ${ }^{*}$ Center of Food and Fermentation Technologies, Akadeemia tee 15A, 12618 Tallinn, Estonia \\ †Department of Chemistry and Biotechnology, Tallinn University of Technology, Akadeemia tee 15, 12618 Tallinn, Estonia
}

\begin{abstract}
We applied capillary electrophoresis, liquid chromatography coupled with tandem mass-spectrometry (MS/MS), and ultra-performance liquid chromatography to determine the composition of water-insoluble and water-soluble proteinaceous fractions of the cheese and to study in detail the degradation of caseins during 8 mo of ripening of Estonian high-temperature cooked hard cheese Old Saare. The application of high-resolution and high-accuracy MS/MS enabled identification of more than 3,000 small peptides, representing a fairly full casein peptidome containing peptides of 4 to $25 \mathrm{AA}$ in length: 1,049 from $\beta$-casein $(\mathrm{CN}), 944$ from $\alpha_{\mathrm{S} 1}-\mathrm{CN}$, 813 from $\alpha_{\mathrm{S}_{2}} \mathrm{CN}$, and 234 from $\kappa$-CN. The majority of $\beta$-CN- and $\alpha_{\mathrm{S}_{1}}-\mathrm{CN}$-derived peptides originated from the N-terminal parts of the molecule, f6-93 and f1-124, respectively; peptides from $\alpha_{\mathrm{S} 2}$ - $\mathrm{CN}$ arose predominantly from the C-terminal end f100-162. At the beginning of ripening, we found a relatively high amount of peptides originating from the glycomacropeptide part of $\kappa-\mathrm{CN}$, whereas peptides from para- $\kappa-\mathrm{CN}$ prevailed during the later stages of ripening of the cheese. The cleavage patterns of $\beta-\mathrm{CN}, \alpha_{\mathrm{S}^{2}} \mathrm{CN}$, as well as $\alpha_{\mathrm{S}^{-}} \mathrm{CN}$, showed that primary proteolysis was started mainly by plasmin, although a low proteolytic activity of chymosin was also evident. Based on the analysis of cleavage sites, we observed a significant participation of proteolytic enzymes, including amino- and carboxypeptidases, of both mesophilic and thermophilic starter bacteria in further hydrolysis of oligopeptides during the ripening. Several new phosphopeptides were detected in the result of MS/MS data analysis. The profiles of the estimated concentrations of phosphopeptides revealed that those originating from $\beta-\mathrm{CN}$ and $\alpha_{\mathrm{S1}^{-}} \mathrm{CN}$ accumulated during cheese maturation. In contrast, we did not notice any generation of phosphopeptides from the highly phosphorylated part of $\alpha_{S_{2}}-\mathrm{CN}$, f25-80, presumably due
\end{abstract}

Received March 28, 2017.

Accepted September 3, 2017.

${ }^{1}$ Corresponding author: anastassia@tftak.eu to the inaccessibility of this region to the action of plasmin and chymosin. The analysis of cleavage sites and the combination of principal component and clustering analyses provided a characterization of the complex dynamics of formation and degradation of peptides during cheese maturation. We made an attempt to obtain a comprehensive picture of proteolysis during Old Saare cheese ripening on the basis of the detailed peptidomic data, including also the less abundant peptides determined by MS/MS, and complemented by the data on intact caseins and free AA and reported the results in the paper.

Key words: high-cooked cheese, cheese ripening, proteolysis, cheese peptidomics

\section{INTRODUCTION}

Proteolysis is one of the most important biochemical processes during cheese ripening, manifesting itself as a continuous accumulation of small peptides and free amino acids (FAA), leading to the formation of aroma compounds and contributing to both flavor and texture of cheeses (Fox and McSweeney, 1996). In the high-temperature cooked cheeses, plasmin is the primary proteolytic agent (Upadhyay et al., 2004), which hydrolyzes intact caseins into large (water-insoluble) and intermediate-sized (water-soluble) peptides (Sousa et al., 2001), whereas chymosin is largely thermally inactivated (Hayes et al., 2002; Sheehan et al., 2007). Cell envelope proteinases (CEP) of lactic acid bacteria (LAB) act subsequently on primary hydrolysis products of casein, and after peptides of appropriate size have been formed, bacterial transporters transfer them into cytoplasms of LAB for further degradation by intracellular peptidases into smaller peptides and FAA (Kunji et al., 1996). The release of peptides is further facilitated by the lysis of starter and nonstarter LAB releasing their intracellular peptidases into cheese environment (Wilkinson and Kilcawley, 2005). From the initial steps of cheesemaking up to the end of ripening, the starter survival and enzymatic activities after lysis of cells are determined by temperature, $\mathrm{NaCl}$ concentration, and pH (Gatti et al., 2008). 
In high-temperature cooked cheeses, thermophilic LAB Lactobacillus helveticus is a major proteolytic agent, which produces a large amount of casein degradation products during cheese ripening (Hynes et al., 2003; Milesi et al., 2011). Streptococcus thermophilus is known to have lesser proteolytic activity (Callanan and Ross, 2004), but has been also shown to generate numerous peptides from different caseins (Miclo et al., 2012). Although the protease activity of LAB appears to be strain dependent, the common cleavage sites have been identified for some of the strains in vitro conditions (Kunji et al., 1996; Scolari et al., 2006; Jensen et al., 2009; Miclo et al., 2012; Sadat-Mekmene et al., 2013). The detailed information available on proteolytic systems of LAB allows to make an attempt to assign the enzyme activities to the origin of peptides in cheese.

Proteolysis in cheese during ripening has been extensively studied. Characterization of overall extent of proteolysis is often limited to unspecific determination of $\mathrm{N}$ content of the particular protein degradation fractions in cheese (Ardö, 1999; Milesi et al., 2011). Chromatographic methods have been widely used for the separation of casein molecules and their degradation products, for the dynamics of general profiles of water-soluble peptides, and for the quantification of FAA (Ardö and Gripon, 1995). More recently, capillary electrophoresis $(\mathbf{C E})$ has been applied for more efficient separation of the water-insoluble fraction and identification of the products of primary proteolysis in different cheese varieties during ripening (Albillos et al., 2005; Rodriguez-Nogales and Vázquez, 2007; Rehn et al., 2010). The application of MS in the analysis of proteolysis has contributed to the identification of most abundant water-soluble peptides or particular peptides of interest (Gagnaire et al., 2001; Ardö et al., 2007; Piraino et al., 2007; Sforza et al., 2012; Sánchez-Rivera et al., 2014). These data have been further used to deduce the relationship between specific starter cultures added to cheese and the formation of certain casein hydrolysis products. Much less is known, however, how parallel hydrolysis cascades of peptides take place during ripening. The application of high-resolution and high-accuracy MS instruments developed for protein chemistry enables simultaneous study of the thousands of peptide components (Hu et al., 2005) and can assist in increasing the understanding of proteolytic events in cheese.

In this study, we analyzed proteolysis in Old Saare cheese, a high-temperature $\left(52^{\circ} \mathrm{C}\right)$ cooked variety manufactured in Estonia from pasteurized bovine milk coagulated by rennet and containing both mesophilic and thermophilic LAB and ripened for 8 mo. We monitored industrial production of Old Saare cheese throughout ripening applying $\mathrm{CE}$, liquid chromatography coupled with tandem mass spectrometry (LC-MS/MS), and ultra-performance liquid chromatography (UPLC). The aim of this study was to identify a possibly wide range of the proteolysis products (intact caseins, long water-insoluble and water-soluble peptides, and FAA) and to show their changes in the content during ripening of Old Saare cheese.

\section{MATERIALS AND METHODS}

\section{Cheese Manufacture and Sampling}

Two controlled industrial trials of Old Saare cheese manufacturing were carried out in the Saaremaa Dairy Plant (Estonia) at the same day. Cow milk for cheeses was collected either from 1 (first trial) or 3 farms (second trial) on the island of Saaremaa. The cheese milk was bactofuged and pasteurized at $72^{\circ} \mathrm{C}$ for $23 \mathrm{~s}$. ChyMax rennet and DVS starter cultures DCC-260 and EMFOUR (both from Chr. Hansen Ltd., Hørsholm, Denmark) were used. According to the manufacturer information, the starter cultures used contained strains of mesophilic and thermophilic LAB of the following species: Lactococcus lactis ssp. lactis, Lc. lactis ssp. cremoris, Lc. lactis ssp. diacetylactis, Leuconostoc mesenteroides ssp. cremoris, Streptococcus thermophilus, Lactobacillus casei, Lb. acidophilus, and Lb. helveticus in unspecified proportions. Cheeses were produced in $15-\mathrm{kg}$ blocks, salted in brine to a content of $1.2 \%$ in the cheese, and ripened for 8 mo.

Cheese blocks were analyzed after pressing (1-d-old cheese), after 2 wk of ripening, and subsequently once per month during the ripening period of 8 mo. Cheese blocks were sampled from the interior part, and at each sampling time 2 pieces of cheese were taken from each of both cheese blocks obtained from 2 cheesemaking trials. Thus, all data presented in our work (except moisture content and $\mathrm{pH}$ of cheese) show mean values calculated from 4 replicates characterizing 2 cheesemaking trials analyzed at 10 ripening points. Moisture content and $\mathrm{pH}$ of cheeses were measured at the dairy using a moisture analyzer Precisa XM60 (Precisa Gravimetrics AG, Dietikon, Switzerland; ISO, 2004) and a pH meter (Mettler-Toledo Ltd., Leicester, UK), respectively.

\section{Sample Preparation for CE, LC-MS/MS, UPLC, and Kjeldahl Analyses}

Citrate dispersions (CD) of cheeses were prepared by mixing $5 \mathrm{~g}$ of grated cheese with $20 \mathrm{~mL}$ of $0.5 \mathrm{M}$ trisodium citrate solution at 50 to $55^{\circ} \mathrm{C}$ using a combined hot-plate magnetic stirrer with multiple stirring positions (RT 15 Power IKAMAG, IKA-Werke GmbH \& Co, Staufen im Breisgau, Germany) for approximately 
60 min until complete dissolution of cheese. Thereafter, sample volume was raised to $100 \mathrm{~mL}$ with ultrapure laboratory-grade water (Milli-Q) and centrifuged at $1,630 \times \mathrm{g}$ at $4^{\circ} \mathrm{C}$ for $30 \mathrm{~min}$ to remove fat. Samples were stored at $-20^{\circ} \mathrm{C}$ until further analysis with CE.

Water-soluble extracts (WSE) of cheeses were prepared by homogenizing $2.5 \mathrm{~g}$ of grated cheese in 22.5 $\mathrm{mL}$ of Milli-Q water (12,500-13,000 rpm) using Polytron PT 2100 dispersing aggregate with a diameter of $20 \mathrm{~mm}$ (Kinematica AG, Luzern, Switzerland), followed by heating for $10 \mathrm{~min}$ at $75^{\circ} \mathrm{C}$ and centrifugation for $20 \mathrm{~min}$ at $4^{\circ} \mathrm{C}$ at $13,304 \times \mathrm{g}$. Supernatant was frozen in 1.5-mL Eppendorf Protein LoBind microcentrifuge tubes (Eppendorf AG, Hamburg, Germany) and stored at $-20^{\circ} \mathrm{C}$ until further purification and analysis with LC-MS/MS and UPLC.

Total N (TN) content in CD and WSE of cheeses was determined by the Kjeldahl method. To obtain a total content of different fractions needed for further estimation of the concentrations of individual proteins and peptides determined by CE and LC-MS/MS analyses, a factor of 6.38 was applied for conversion of $\mathrm{N}$ to the content of proteinaceous compounds. We used the value of the conversion factor of 6.38 determined for milk which was also proposed to be used for cheese and other dairy products (Maubois and Lorient, 2016).

\section{Analysis of Intact Caseins and Long Peptides}

Intact caseins and primary proteolysis products in cheeses were analyzed by $\mathrm{CE}$ according to the method described by Ardö and Polychroniadou (1999). The CD samples of cheeses were mixed with a sample buffer (1:1), incubated for $1 \mathrm{~h}$ at room temperature, filtered through a $0.45-\mu \mathrm{m}$ polyvinylidene fluoride (PVDF) filter (Merck Millipore Ltd., Tullagreen, Carrigtwohill, County Cork, Ireland), and loaded into $100-\mu \mathrm{L}$ vials for $\mathrm{CE}$ analysis. Sample buffer ( $\mathrm{pH} 8.6$ ) consisted of $10 \mathrm{M}$ urea, $0.83 \mathrm{~g} / \mathrm{L}$ of methylhydroxyethylcellulose, $167 \mathrm{mM}$ Tris, $67 \mathrm{~m} M$ disodium EDTA, $42 \mathrm{mM} 3$-( $N$-morpholino) propanesulfonic acid, and $17 \mathrm{mM}$ dithiothreitol.

The CE analyses were carried out with the Agilent CE System (Agilent Technologies, Waldbronn, Germany) with diode-array detection. Separations were performed using a neutral polyvinyl alcohol coated capillary column (Agilent Technologies Finland Oy, Espoo, Finland) of $56 \mathrm{~cm}$ effective length and $50 \mu \mathrm{m}$ i.d., at a temperature of $45^{\circ} \mathrm{C}$ with a linear voltage gradient from 0 to $25 \mathrm{kV}$ in $3 \mathrm{~min}$, followed by a constant voltage of $25 \mathrm{kV}$. Separation buffer ( $\mathrm{pH} 3.0$ ) contained $20 \mathrm{mM}$ trisodium citrate, $190 \mathrm{~m} M$ citric acid, $0.5 \mathrm{~g} / \mathrm{L}$ methylhydroxyethylcellulose, and $6 M$ urea. The samples were injected by pressure at $34.0 \mathrm{mbar}$ for $20 \mathrm{~s}$. Proteinaceous fractions were detected by UV absorbance at $214 \mathrm{~nm}$.
Proteinaceous fractions were identified by injection of milk protein standards ( $\alpha-\mathrm{LA}, \beta-\mathrm{LG}, \kappa-\mathrm{CN}, \beta-\mathrm{CN}$, and $\alpha_{S^{-}} \mathrm{CN}$; Sigma-Aldrich Co. LLC, St. Louis, MO) and by comparison of obtained electropherograms with those presented in literature (Otte et al., 1997; Miralles et al., 2003; Albillos et al., 2007; Heck et al., 2008). The peaks were integrated after setting the baseline from valley to valley (Miralles et al., 2003).

\section{Analysis of Water-Soluble Peptides}

$\boldsymbol{L} \boldsymbol{C}-\boldsymbol{M S} / \boldsymbol{M S}$ Analysis. The WSE samples of cheeses were purified with C18 StageTips (Thermo Fisher Scientific Inc., Waltham, MA) according to Rappsilber et al. (2007) protocol, and analyzed by LC-MS/MS using an Agilent 1200 series nanoflow system (Agilent Technologies, Santa Clara, CA) connected to a Thermo Scientific LTQ Orbitrap MS equipped with a nanoelectrospray ion source (Proxeon, Odense, Denmark). Purified peptides were dissolved in $0.5 \%$ trifluoroacetic acid, and $2 \mu \mathrm{g}$ of peptide fractions were loaded on a self-packed fused silica emitter $(150 \mathrm{~mm} \times 0.075 \mathrm{~mm}$, Proxeon) packed with ReproSil-Pur C18-AQ $3 \mu \mathrm{m}$ particles (Dr. Maisch, Ammerbuch, Germany) using a flow rate of $0.7 \mu \mathrm{L} / \mathrm{min}$. Peptides were separated with a 240 min gradient from 8 to $40 \%$ B (A: $0.5 \%$ acetic acid, B: $0.5 \%$ acetic acid $/ 80 \%$ acetonitrile) using a flow rate of $0.2 \mu \mathrm{L} / \mathrm{min}$ and sprayed directly into the MS operated at $220^{\circ} \mathrm{C}$ capillary temperature and $2.2 \mathrm{kV}$ spray voltage.

Full mass spectra were acquired in a profile mode, with a mass range from $\mathrm{m} / z 300$ to 1,800 at the resolving power of 60,000 at $\mathrm{m} / z 400$. Up to five datadependent MS/MS spectra were acquired in centroid in the linear ion trap for each FTMS full-scan spectrum, and each fragmented ion was dynamically excluded for 80 s. Full scans were performed after the accumulation of 1,000,000 charges, whereas fragmentation scans required the accumulation of 5,000 charges, and ion injection times were 500 and $150 \mathrm{~ms}$, respectively. Monoisotopic precursor selection was enabled, ions with a charge state of $\geq 1+$ were selected for fragmentation, and unassigned charge states were rejected.

Database Search. Raw MS/MS files from the LTQ Orbitrap were analyzed with MaxQuant software package (version 1.5.2.8; Cox and Mann, 2008). The MS/ MS spectra were searched against a protein sequence database containing the following casein genetic variants: $\mathrm{A}, \mathrm{B}$, and $\mathrm{C}$ variants for $\alpha_{\mathrm{S}_{1}} \mathrm{CN} ; \mathrm{A}$ and $\mathrm{C}$ for $\alpha_{S_{2}-} \mathrm{CN} ; \mathrm{A}^{1}, \mathrm{~A}^{2}, \mathrm{~A}^{3}$, and $\mathrm{B}$ variants for $\beta-\mathrm{CN}$; and $\mathrm{A}, \mathrm{B}$, $\mathrm{E}$, and $\mathrm{F}^{1}$ variants for $\kappa-\mathrm{CN}$ (Farrell et al., 2004; Caroli et al., 2009) and the MaxQuant built-in common contaminants database (245 entries). The search was done against both forward and reverse protein sequences by 
the Andromeda search engine (Cox et al., 2011). Parent mass and fragment ions were searched with a maximal initial mass deviation of $7 \mathrm{mg} / \mathrm{kg}$ and $0.5 \mathrm{Da}$, respectively. The search included the following variable modifications: methionine oxidation, $\mathrm{N}$-terminal acetylation, N-terminal glutamine and asparagine deamination, formation of S-S disulfide bonds, and phosphorylation of Ser, Thr, and Tyr. The peptide search included peptides in the length range from 4 to $25 \mathrm{AA}$. For peptide identification, the false discovery rate was set to 0.01 , and the "match between runs" search function was used to improve peptide quantification coverage.

\section{Analysis of FAA}

Analysis of FAA was performed by a UPLC system (Acquity UPLC, Waters Corp., Milford, MA), including a binary solvent manager, a sample manager, and a photodiode array detector, controlled by Waters Empower 2.0 software. Separations were performed on a $2.1 \times 100 \mathrm{~mm}$ Waters Acquity UPLC AccQ.Tag Ultra Column operated at $55^{\circ} \mathrm{C}$ and equilibrated with AccQ.Tag Ultra eluent A (Waters Corp.). The WSE samples of cheeses were mixed with isopropanol (1:1) to precipitate the proteins, centrifuged for $5 \mathrm{~min}$ at $4^{\circ} \mathrm{C}$ at $13,304 \times g$, and filtered through a $0.2-\mu \mathrm{m}$ PTFE filter (Merck Millipore Ltd.). Before the injection, FAA were derivatized with AccQ·Fluor Reagent (Waters Corp.) according to the manufacturer's procedure. The injection volume was $1.0 \mu \mathrm{L}$, the AA were eluted at a flow rate of $0.3 \mathrm{~mL} / \mathrm{min}$ using a linear gradient of 0 to $100 \%$ of AccQ.Tag Ultra eluent B (Waters Corp.), and the absorbance was recorded at $260 \mathrm{~nm}$. Empower software (Waters Corp.) was used for data processing. The absolute concentrations of AA were calculated using standard curves, and individual AA were also expressed as a relative content of the total amount of $\mathrm{AA}(\mathrm{mol} \%)$.

\section{Data Analysis}

Semi-Quantification of Proteins and Peptides. For calculation of the estimated concentrations of protein and peptide components identified by $\mathrm{CE}$ and LC-MS/MS analyses, the peak areas from electropherograms and the MS/MS intensities were normalized and recalculated in terms of grams per kilogram of cheese, using the content of proteinaceous compounds determined in CD $\left(C D_{\text {prot }}\right)$ and WSE (WSE $\left.E_{\text {prot }}\right)$ fractions by the Kjeldahl method, and total concentration of FAA, as presented below.

The intact caseins and the products of primary hydrolysis determined by $\mathrm{CE}$ were recalculated as follows:

$$
C_{x}=\frac{\frac{A_{x}}{t_{x}} \times\left(C D_{\text {prot }}-W S E_{\text {prot }}\right)}{\sum_{i=1}^{n} \frac{A_{i}}{t_{i}}},
$$

where $C_{x}$ is the estimated concentration of fraction $x$ ( $\mathrm{g} / \mathrm{kg}$ of cheese); $A_{x}$ is the area in the electropherogram of fraction $x ; t_{x}$ is the migration time of fraction $x$; and $n$ is the total number of the peaks.

The MS/MS intensities of small peptides were recalculated using the following equation:

$$
C_{y}=\frac{I_{y} \times\left(W S E_{\text {prot }}-F A A\right)}{\sum_{i=1}^{n} I_{i}},
$$

where $C_{y}$ is the estimated concentration of the peptide $y\left(\mathrm{~g} / \mathrm{kg}\right.$ of cheese); $I_{y}$ is the intensity of the peptide $y$; $n$ is the total number of peptides identified by MS/MS; and FAA is the total concentration of FAA determined by UPLC.

Further the concentrations of identified CE fractions and small peptides were recalculated to $\mathrm{mol} / \mathrm{kg}$ of cheese using molar weights. As we could not estimate a true ratio between fully, partially, and nonphosphorylated copies of phosphopeptides, the molar weights of the phosphate groups were not taken into account in the recalculation of phosphopeptides to $\mathrm{mol} / \mathrm{kg}$ of cheese.

For the calculations we assumed that the larger part of peptides longer than $25 \mathrm{AA}$ and not covered by MS/ MS analysis has been eluted in the CE electropherograms as unidentified peaks, those areas were also taken into account in all calculations. Also we assumed that di- and tripeptides were rapidly degraded into FAA by the enzymes of LAB, and hardly accumulated in the cheese mass in significant amounts. Urea and ammonia were not measured in the fraction either, which might have led to some overestimation of the total amount of small water-soluble peptides in the WSE.

Treatment of MS/MS Data. Calculations and visualizations were performed using in-house data analysis routines implemented in Python programming language (Python Software Foundation, version 3.5, available at http://www.python.org) based on all 3,040 casein-derived small peptides identified by LC-MS/MS.

To look in more detail at the most abundant peptides present in cheese during ripening, peptides were selected based on their estimated molar concentrations and subjected to further analysis. At each time point, the most abundant peptides that accounted for altogether at least $50 \%$ of all small peptides by molar abundance were sorted out. At each ripening time, 54 
to 83 peptides met this criterion; altogether, 169 peptides (48 from $\alpha_{\mathrm{S}_{1}} \mathrm{CN}, 20$ from $\alpha_{\mathrm{S}_{2}} \mathrm{CN}$, and 101 from $\beta-\mathrm{CN})$ were selected and subjected to principal component analysis (PCA) and clustering analysis. The data set corresponding to 169 individual peptides was first preprocessed using centering and autoscaling, followed by PCA. This approach has 2 advantages. Firstly, after normalization, the clustering is based on the peptide concentration profiles rather than on their estimated concentration. Secondly, by selecting a limited number of principal components (PC), the clustering is based only on most obvious profile features while reducing the noise in individual profiles. Explained variance and eigenvalues of individual PC of PCA were used to select the appropriate number of PC. Four PC described $>90 \%$ of the variance. After that, additional PC added a little to total explained variance. Therefore, data corresponding to the first $4 \mathrm{PC}$ of individual peptides were chosen for clustering analysis. In clustering analysis, k-means clustering was applied. The algorithm aims to separate $\mathrm{n}$ samples into $\mathrm{k}$ groups, in which each observation belongs to the group with the nearest mean. Therefore, k-means clustering takes the total number of groups as the input parameter. Several values for the total number of groups were tested. In total, 4 groups were chosen as optimal, as the average deviance of individual peptides profiles from the groups mean was the smallest. When using less than 4 groups, the deviance increased dramatically. When more groups than 4 were formed, the profiles of several groups looked very similar, indicating that these peptides had similar behavior.

\section{RESULTS AND DISCUSSION}

\section{Gross Composition of Cheese and Overall Distribution of Proteolysis Fractions}

The moisture content decreased from 38.5 to $35.5 \%$ (wt/wt) and $\mathrm{pH}$ increased approximately from 5.3 to 5.7 during 8 mo of the cheese ripening (Table 1).

The mean value of TN content in Old Saare cheese was $42.1 \pm 0.8 \mathrm{~g} / \mathrm{kg}$ of cheese and did not differ significantly during the ripening $(P<0.05)$. Figure 1 shows the changes in overall estimated composition of caseins and their degradation products throughout the ripening process. In 1-d-old cheese, intact caseins comprised approximately $78 \%$ of $\mathrm{TN}$ and decreased to $25 \%$ of total TN in the 8 -mo-old cheese (Figure 1). The content of water-soluble N (WSN), including watersoluble peptides and FAA, increased almost 10-fold from $1.3 \pm 0.0$ to $12.8 \pm 0.3 \mathrm{~g} / \mathrm{kg}$, and comprised about $29 \%$ of TN by the end of the ripening. Hydrolysis of full-length caseins and accumulation of WSN fraction was particularly pronounced during the first $4 \mathrm{mo}$; the concentration of WSN increased by approximately 2.5 $\mathrm{g} / \mathrm{kg}$ of cheese per mo. In general, the ripening of Old Saare was characterized by a high extent and depth of proteolysis. The ratio of WSN to TN in the 8-mo-old Old Saare was somewhere in between that observed in 24-mo ripened Parmesan (32-36\%) and 6-mo-old Cheddar (24-25\%; Careri et al., 1996; Barrett et al., 1999).

\section{Primary Proteolysis}

The CD fraction of Old Saare cheese resolved into 43 prominent peaks on the CE curves (Figure 2). From these, we identified 15 peaks either as intact caseins: $\alpha_{\mathrm{S} 1}-\mathrm{CN}(8 \mathrm{P}$ and $9 \mathrm{P}), \alpha_{\mathrm{S} 2}-\mathrm{CN}(11 \mathrm{P}, 12 \mathrm{P}$, and $\mathrm{nP}), \beta-\mathrm{CN}$ (with genetic variants $\mathrm{A}^{1}, \mathrm{~A}^{2}$, and $\mathrm{B}$ ), and para- $\kappa-\mathrm{CN}$ [regarded as intact in this study as the vast majority of $\kappa-\mathrm{CN}$ is hydrolyzed to para- $\kappa-\mathrm{CN}$ and glycomacropeptide (GMP) already during the vat process before ripening], or their breakdown products: $\alpha_{\mathrm{S}_{1}}-\mathrm{I}-\mathrm{CN}$ (8P and $9 \mathrm{P}), \gamma_{1}-\mathrm{CN}\left(\mathrm{A}^{1}\right.$ and $\left.\mathrm{A}^{2}\right), \gamma_{2}-\mathrm{CN}$, and $\gamma_{3}-\mathrm{CN}$. Twenty-eight prominent peaks could not be assigned to any specific casein fraction (marked with numbers on sample electropherograms in Figure 2), but were considered as casein degradation products due to their mainly increasing behavior during cheese ripening (an overall change of this fraction during the ripening is shown in Figure 1). Unidentified peaks can refer presumably to primary hydrolysis products of $\alpha_{\mathrm{S}^{-}} \mathrm{CN}$ or to some water-insoluble large peptides derived from $\alpha_{\mathrm{S1}^{-}}$ $\mathrm{CN}$ and $\beta-\mathrm{CN}$ produced by the action of proteinases other than chymosin and plasmin.

Among all caseins, $\beta$-CN was subjected to most extensive degradation; compared to the 1 -d-old cheese we found about $80 \%$ of $\beta$-CN hydrolyzed during 8 mo of

Table 1. Moisture content and $\mathrm{pH}$ of Old Saare cheese during ripening ${ }^{1}$

\begin{tabular}{|c|c|c|c|c|c|}
\hline \multirow[b]{2}{*}{ Item } & \multicolumn{5}{|c|}{ Ripening time } \\
\hline & $1 \mathrm{~d}$ & $1 \mathrm{mo}$ & $3 \mathrm{mo}$ & $5 \mathrm{mo}$ & $8 \mathrm{mo}$ \\
\hline $\begin{array}{l}\text { Moisture content, \% } \\
\mathrm{pH}\end{array}$ & $\begin{array}{l}38.5 \pm 0.1 \\
5.27 \pm 0.04\end{array}$ & $\begin{array}{l}36.5 \pm 0.0 \\
5.30 \pm 0.00\end{array}$ & $\begin{array}{l}36.1 \pm 0.5 \\
5.44 \pm 0.01\end{array}$ & $\begin{array}{l}35.8 \pm 0.2 \\
5.40 \pm 0.00\end{array}$ & $\begin{array}{l}35.5 \pm 0.0 \\
5.67 \pm 0.04\end{array}$ \\
\hline
\end{tabular}


ripening (Table 2). The hydrolysis of intact $\alpha_{\mathrm{S}_{2}} \mathrm{CN}$ was also very high $(78 \%)$, the corresponding value for $\alpha_{\mathrm{S}^{-}}$ $\mathrm{CN}$ was $65 \%$, and for para-k-CN only $37 \%$ (Table 2 ).

We observed a strong contribution of plasmin to the hydrolysis of $\beta$-CN already in the 1-d-old cheese: $\gamma$-CN formed $21 \%$ of water-insoluble $\beta$-CN-derived fraction, and $8.2 \%$ of total proteinaceous fraction (Table 2). In contrast, $\alpha_{\mathrm{S} 1}-\mathrm{I}-\mathrm{CN}$, the primary hydrolysis product of $\alpha_{S_{1}}$ CN generated by chymosin, formed only $1.4 \%$ of $\alpha_{S 1}$-CN water-insoluble fraction ( $0.4 \%$ of total proteinaceous fraction) in the 1-d-old cheese. This is in agreement with the fact that $\beta$-CN hydrolysis by plasmin

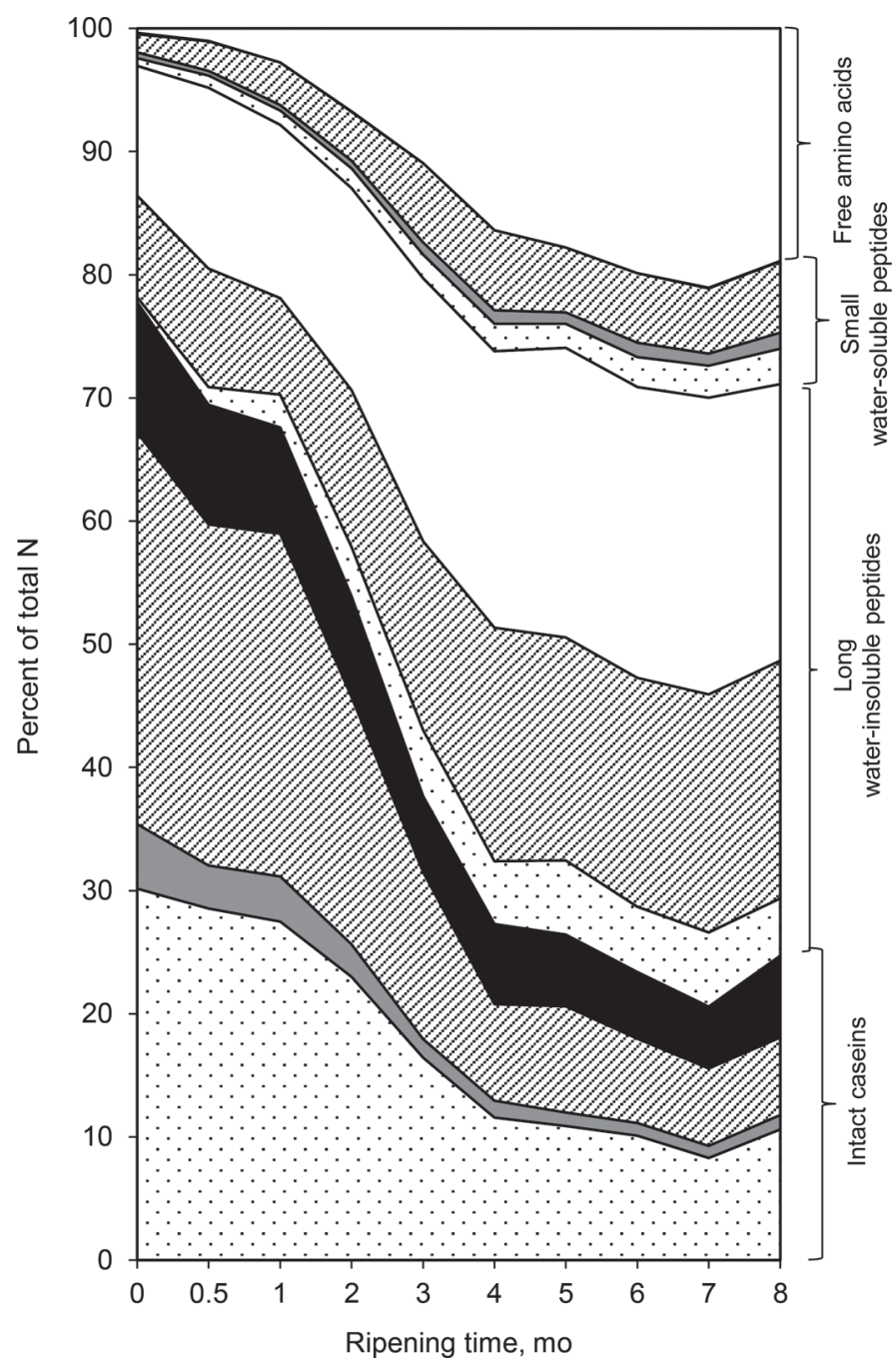

Figure 1. Estimated distribution of the main casein fractions during the ripening of Old Saare cheese within the intact caseins, long water-soluble peptides, and small water-soluble peptides: dotted areas represent $\alpha_{\mathrm{S}^{-}} \mathrm{CN}$, gray areas represent $\alpha_{\mathrm{S2}^{2}} \mathrm{CN}$, striped areas represent $\beta-\mathrm{CN}$, and black areas represent $\kappa-\mathrm{CN}$ and their degradation products. Unidentified long peptides determined by capillary electrophoresis and free AA are represented by white areas. Results represent the mean values of duplicated samples from each of 2 cheesemaking trials $(\mathrm{n}=$ $4)$. starts already in milk, while $\alpha_{\mathrm{S} 1}-\mathrm{CN}$ is not hydrolyzed by chymosin during milk coagulation, but is degraded in cheese during ripening (Upadhyay et al., 2004). On the other hand, despite the large differences in the initial levels of $\gamma-\mathrm{CN}$ and $\alpha_{\mathrm{S} 1}-\mathrm{I}-\mathrm{CN}$ at the beginning of the ripening, the hydrolysis of $\alpha_{S_{1}}-\mathrm{CN}$ and $\beta-\mathrm{CN}$ showed similar trends and degradation rates, which were the highest within the first 4 mo of cheese ripening (Figure $3 \mathrm{a}$ ); the content of intact $\beta$-CN decreased approximately $0.7 \mathrm{mmol} / \mathrm{kg}$ of cheese per month and that of $\alpha_{\mathrm{S} 1}{ }^{-} \mathrm{CN}$ decreased $0.6 \mathrm{mmol} / \mathrm{kg}$ of cheese per month. During the remaining period, the breakdown of $\beta-\mathrm{CN}$ and $\alpha_{\mathrm{S} 1}-\mathrm{CN}$ was insignificant or very modest. Likewise, the content of $\alpha_{S^{2}}$ CN decreased rapidly during the first $3 \mathrm{mo}$ of ripening (Table 2), the degradation rate slowing during further ripening. In parallel with the degradation of $\beta-\mathrm{CN}$ and $\alpha_{\mathrm{S}_{1}}-\mathrm{CN}$ intact fractions, $\gamma-\mathrm{CN}$ content increased steadily up to $4 \mathrm{mo}$, and $\alpha_{\mathrm{S} 1}-\mathrm{I}-\mathrm{CN}$ content, up to 3 mo of ripening (Figure 3b). Although Old Saare cheese is produced using quite high scalding temperature $\left(52^{\circ} \mathrm{C}\right)$, the considerable degradation of intact $\alpha_{\mathrm{S} 1^{-}}$ $\mathrm{CN}$ in parallel with the production of $\alpha_{\mathrm{S} 1}-\mathrm{I}-\mathrm{CN}$ may indicate a substantial residual activity of chymosin in Old Saare cheese. Chymosin is known to be quite susceptible to irreversible thermal denaturation in liquid environment, but has been shown to be only partially and reversibly inactivated when bound to casein matrix during curd cooking at high temperatures and can even regain its activity after initial inactivation (Hayes et al., 2002; Sheehan et al., 2007). On the contrary, the contribution of plasmin to primary proteolysis is well defined in cheeses cooked at higher temperatures (Kaminogawa et al., 1972; Sousa et al., 2001; Sheehan et al., 2007), probably due to inactivation of plasminogen activator inhibitors (Farkye and Fox, 1990). Our results on $\beta$-CN degradation in the high-temperature cooked Old Saare cheese are consistent with these observations, even though the initial $\mathrm{pH}$ of the fresh cheese $(\mathrm{pH} 5.3)$ has been rather low for optimal plasmin action (Table 1). It is noteworthy that the dynamics of content of individual $\gamma-\mathrm{CN}$ was quite different throughout the ripening: the rates of $\gamma_{1}-\mathrm{CN}$ and $\gamma_{3}-\mathrm{CN}$ accumulation during the first 4 mo were much higher than that of $\gamma_{2}-\mathrm{CN}$, content of which changed very slowly during the entire ripening.

\section{Dynamics of Small Peptides}

In total, we identified 3,266 unique water-soluble peptides (4-25 AA in length) by LC-MS/MS analysis (Supplemental Table S1; https://doi.org/10.3168/jds .2017-12944). From those, 944 arose from $\alpha_{\mathrm{S} 1}-\mathrm{CN}, 813$ from $\alpha_{\mathrm{S}^{-}} \mathrm{CN}, 1,049$ from $\beta-\mathrm{CN}, 234$ from $\kappa-\mathrm{CN}$, and 226 from miscellaneous milk-derived proteins (under 
$0.3 \%$ of total MS/MS intensity): mainly from osteopontin (177 peptides), also from $\beta$-LG (17 peptides), and few peptides from bovine fibrinogen and complement component $\mathrm{C} 7$. The total intensity of peptides from osteopontin obtained by MS/MS in 1-d-old cheese was comparable with the intensity of peptides from GMP part of $\kappa-\mathrm{CN}$. Most of the peptides identified from osteopontin had maximum intensities in 1-d-old cheese, showing a rapid decrease already in 1- to 2-moold cheese and remaining low until the end of ripening. Our results indicated that osteopontin was somehow subjected to proteolysis during ripening of the cheese, but its impact to cheese characteristics is unclear and demands further investigation. Thus, we focused our study on the characterization of the proteolysis of casein components in particular.

Eight hundred eighty-six of all casein-derived peptides identified by MS/MS were found to be potentially phosphorylated. The quantitative proteomics software MaxQuant detected the phosphorylation of casein peptides at the following positions: $\mathrm{Ser}_{41}, \mathrm{Ser}_{46}, \mathrm{Ser}_{48}, \mathrm{Thr}_{49}$, $\mathrm{Ser}_{64}, \mathrm{Ser}_{66}, \mathrm{Ser}_{67}, \mathrm{Ser}_{68}, \mathrm{Ser}_{75}, \mathrm{Ser}_{115}, \mathrm{Ser}_{122}, \mathrm{Ser}_{188}$ in

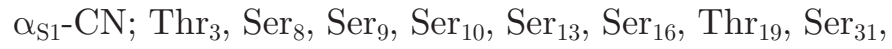
Ser $_{52}$, Ser $_{56}$, Ser $_{57}$, Ser $_{58}$, Ser $_{61}, \mathrm{Thr}_{66}, \mathrm{Ser}_{129}, \mathrm{Thr}_{130}$, $\mathrm{Ser}_{131}, \mathrm{Ser}_{135}, \mathrm{Thr}_{138}, \mathrm{Ser}_{143}, \mathrm{Thr}_{144}$ in $\mathrm{\alpha}_{\mathrm{S} 2} \mathrm{CN} ; \mathrm{Ser}_{15}$,
$\mathrm{Ser}_{17}, \mathrm{Ser}_{18}, \mathrm{Ser}_{19}, \mathrm{Ser}_{22}, \mathrm{Thr}_{24}, \mathrm{Ser}_{35}, \mathrm{Thr}_{41}$ in $\beta-\mathrm{CN}$; and $\mathrm{Ser}_{127}, \mathrm{Thr}_{133}, \mathrm{Thr}_{145}, \mathrm{Ser}_{149}, \mathrm{Ser}_{166}, \mathrm{Thr}_{167}$ in $\kappa$-CN sequence. These phosphorylation positions included all Ser-P sites identified in plasmin-released phosphopeptides of Grana Padano cheese (Ferranti et al., 1997a) and phosphopeptides isolated from semi-hard Herrgård cheese made with mesophilic DL-starter (Lund and Ardö, 2004). In addition, LC-MS/MS technique used in our study allowed to detect phosphopeptides with phosphate groups at all experimentally determined as well as potential phosphorylation sites in caseins reviewed by Farrell et al. (2004), including Thr residues. Also, some new phosphopeptides were found with phosphate groups at sites not previously reported in the literature $\left(\mathrm{Thr}_{49}, \mathrm{Ser}_{122}, \mathrm{Ser}_{188}\right.$ in $\alpha_{\mathrm{S1}} \mathrm{CN} ; \mathrm{Ser}_{13}, \mathrm{Thr}_{19}, \mathrm{Ser}_{52}, \mathrm{Ser}_{135}$, $\mathrm{Thr}_{138}, \mathrm{Thr}_{144}$ in $\alpha_{\mathrm{S}_{2}} \mathrm{CN} ; \mathrm{Ser}_{22}, \mathrm{Thr}_{24}, \mathrm{Thr}_{41}$ in $\beta-\mathrm{CN}$; and $\mathrm{Thr}_{133}, \mathrm{Ser}_{166}$, and $\mathrm{Thr}_{167}$ in $\left.\mathrm{\kappa}-\mathrm{CN}\right)$. Phosphorylation of caseins is a complicated posttranslational modification, which could be influenced by many factors, including genetic expression of protein kinases, substrate availability, and accessibility of the modification site of casein (Holland and Boland, 2014). Some studies have shown the activity of phosphatases from milk or bacteria present in cheeses modifying phosphorylation of peptides (Akuzawa and Fox, 2004). Therefore, the

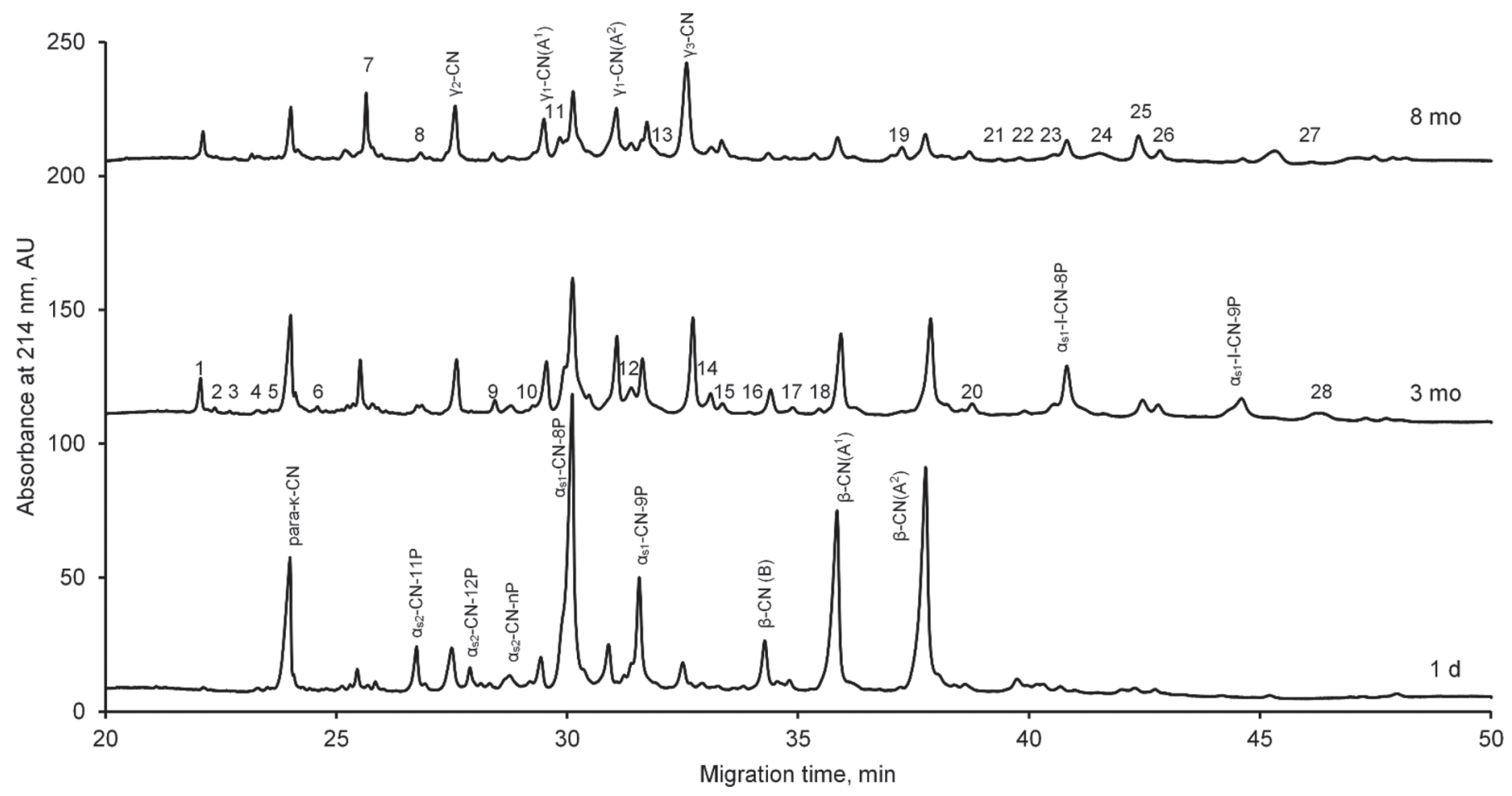

Figure 2. The representative electropherograms of Old Saare cheese obtained by capillary electrophoresis at $1 \mathrm{~d}, 3 \mathrm{mo}$, and 8 mo of ripening. The peaks were identified by injection of milk protein standards and comparison with the profiles presented in literature (Otte et al., 1997; Miralles et al., 2003; Albillos et al., 2007; Heck et al., 2008). Unidentified peaks are marked with numbers 1 to 28. AU = arbitrary units. 
characterization of actual phosphorylation sites of peptides and the degree of modification needs an additional deep analysis of individual phosphopeptides.

An overall change of the content of small peptides was the fastest during the first 3 to 4 mo of ripening (Figure 1, Table 2) and slowed down during the later stages of the ripening, which indicated that the rates of formation and degradation of small peptides became more balanced. Peptides originating from $\beta-\mathrm{CN}$ comprised the largest part (56-69\%) of the small peptides depending on the ripening time, followed by the peptides derived from $\alpha_{\mathrm{S}_{1}} \mathrm{CN}(21-29 \%)$, from $\alpha_{\mathrm{S}_{2}} \mathrm{CN}$ $(8-17 \%)$, and finally from $\kappa$-CN forming 0.1 to $3 \%$ of the whole fraction of small water-soluble peptides.

For a general review of the patterns of small peptides throughout 8-mo ripening of Old Saare cheese, we
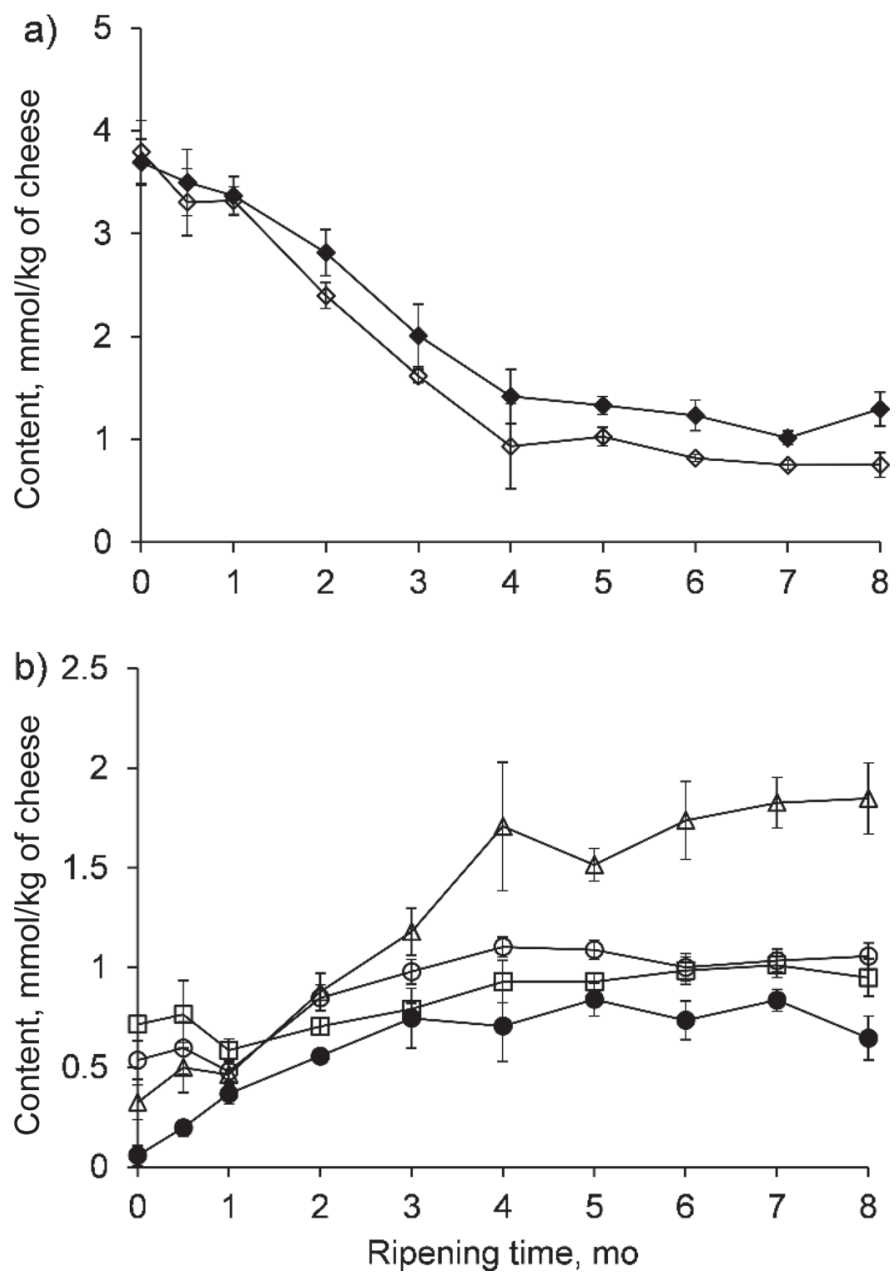

Figure 3. Time course of casein hydrolysis: (a) $\alpha_{\mathrm{S}^{-}} \mathrm{CN}(\bullet)$ and $\beta-\mathrm{CN}(\diamond)$ and their primary degradation products; (b) $\alpha_{\mathrm{S} 1}-\mathrm{I}-\mathrm{CN}(\bullet)$, $\gamma_{1}$-CN $(\bigcirc), \gamma_{2}$ CN $(\square), \gamma_{3}$-CN $(\Delta)$ during the ripening of Old Saare cheese. Results represent the mean estimated concentrations of duplicated samples from each of 2 cheesemaking trials $(n=4)$; vertical bars represent SD.

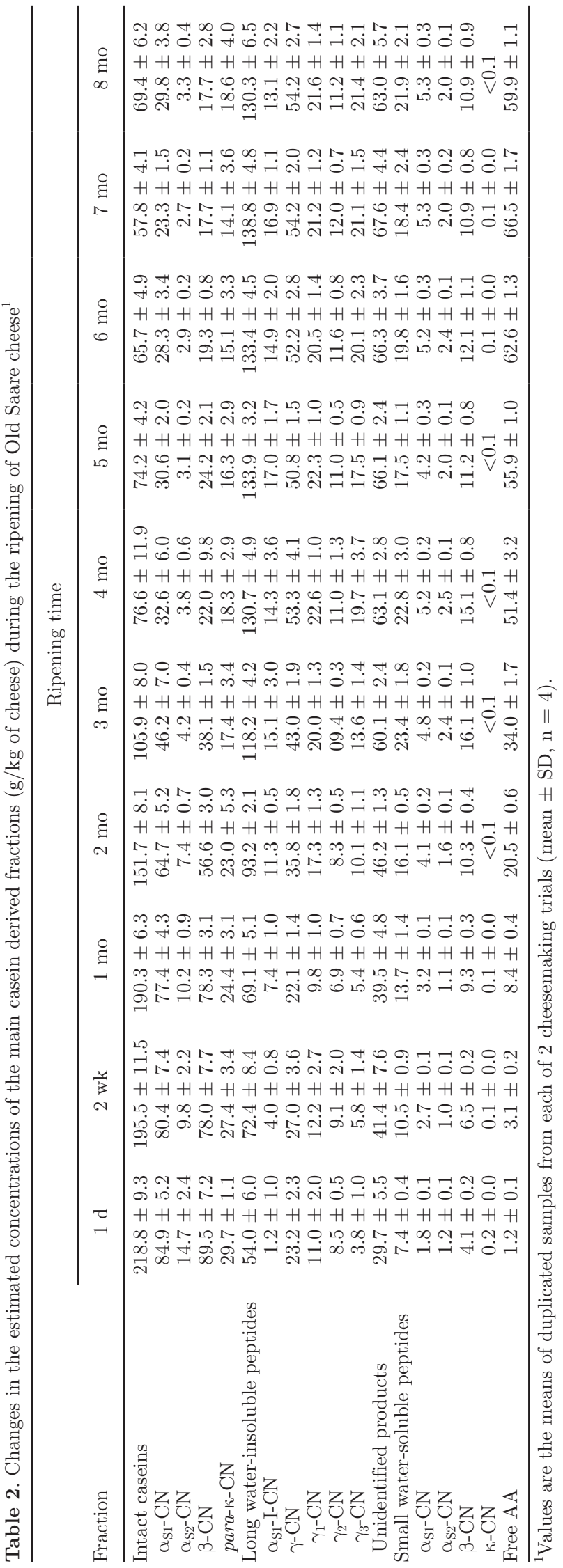

Journal of Dairy Science Vol. 101 No. 2, 2018 

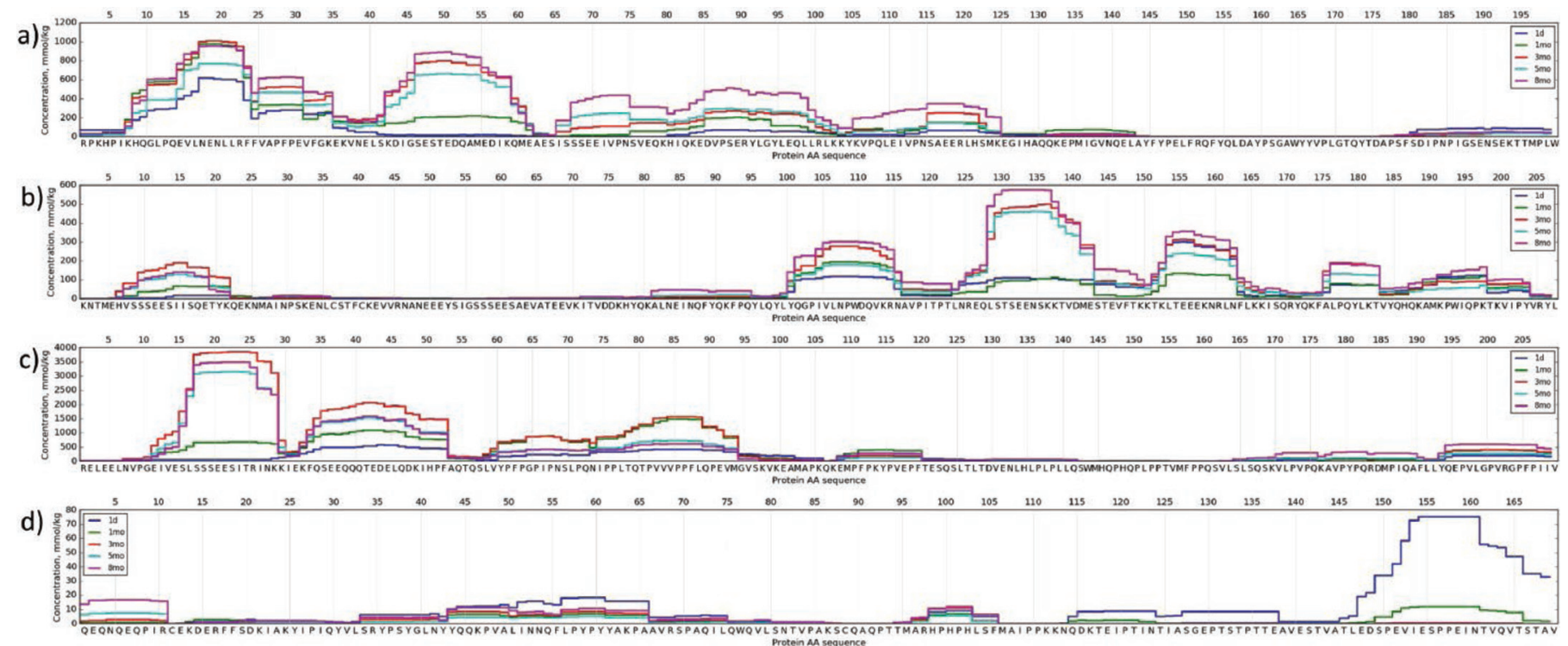

Figure 4. Regions on $\alpha_{\mathrm{S}_{1}} \mathrm{CN}(\mathrm{a}), \alpha_{\mathrm{S} 2}-\mathrm{CN}(\mathrm{b}), \beta-\mathrm{CN}(\mathrm{c})$, and $\kappa-\mathrm{CN}$ (d) sequences where the identified small peptides derive from (based on all 3,040 water-soluble peptides determined by liquid chromatography-MS/MS). Cumulative concentrations of the AA in the identified peptides are plotted on the casein sequences. Results represent the mean estimated concentrations of duplicated samples from each of 2 cheesemaking trials $(\mathrm{n}=4)$.

aligned the identified 3,040 peptides on the corresponding casein sequences and plotted them considering their estimated concentrations in the samples (Supplemental Figure S1; https://doi.org/10.3168/jds.2017-12944). We summed the estimated concentrations of all AA present in identified peptides and located in the same positions along particular protein sequence, and plotted the cumulative concentrations on corresponding sequences to get an overview of the preferable regions of caseins from where the majority of small peptides were derived (Figure 4). Further, to facilitate the analysis of cleavage sites, we also summed the estimated concentrations of all AA corresponding to the N-terminal and C-terminal ends of identified peptides and plotted them on the entire protein sequences (Supplemental Figure S2, https://doi.org/10.3168/jds.2017-12944, and Figure 5).

$\boldsymbol{\beta}-\boldsymbol{C N}$-Derived Small Peptides. The majority of $\beta$-CN-derived water-soluble peptides arose from the Nterminal part of the sequence, f6-93 (Figure 4c). We identified also a significant fraction of peptides from the regions f106-120 and f170-209. However, we observed a very low proteolytic activity on the $\beta-\mathrm{CN}$ sequence f120-170 (Supplemental Figure S1c, https://doi.org/ 10.3168/jds.2017-12944, and Figure 4c). It should be noted also that the amounts of the peptides of $\beta$-CN were significantly higher that the amounts from other casein variants (Figure 4).

Most of the peptides from the region $\beta$-CN f1-28 (Figure 4c) were formed presumably due to the pre- ferred action of plasmin on the bond $\mathrm{Lys}_{28}-\mathrm{Lys}_{29}$ (Fox and McSweeney, 1996) and subsequent activity of bacterial proteinases and peptidases on that fragment. The relative share of these peptides increased from approximately $3.6 \%$ in the 1-d-old cheese up to $40 \%$ of all $\beta$-CN derived peptides by the end of ripening indicating their clear accumulation. A multiphosphorylated peptide $\beta-\mathrm{CN}$ f7-28 formed from f1-28 by the cleavage of the bond $\mathrm{Leu}_{6}-\mathrm{Asn}_{7}$ possibly by CEP of $L c$. lactic and by Lb. helveticus (Kunji et al., 1996), was abundant already in the 1-d-old cheese and remained at high concentrations until the end of the ripening (Table 3 ). Furthermore, 2 peptides, $\beta-\mathrm{CN}$ f7-16 and f17-28, the potential degradation products of $\beta-\mathrm{CN}$ f7 -28 by the action of CEP of lactococci and proteolytic system of St. thermophilus on the bond $\mathrm{Leu}_{16}-\mathrm{Ser}_{17}$ (Kunji et al., 1996; Miclo et al., 2012), were also present in comparable and substantial amounts in the 1-d-old cheese. A significant decrease in relative amounts of mesophilic lactococci during the vat process of Old Saare cheese has been indicated by pyrosequencing of $16 \mathrm{~S} \mathrm{cDNA}$ [L. Blank, Department of Chemistry and Biotechnology, Tallinn University of Technology (TUT), Tallinn, Estonia, personal communication]. Nevertheless, the significant production of peptides $\beta-\mathrm{CN}$ f7-28, f7-16, and f17-28 already in fresh cheese may indicate a high activity of CEP of mesophilic starter bacteria before an actual cheese ripening began. Pyrosequencing of $16 \mathrm{~S}$ cDNA has also shown that during the first month of ripening $L b$. helveticus and St. thermophilus were the 

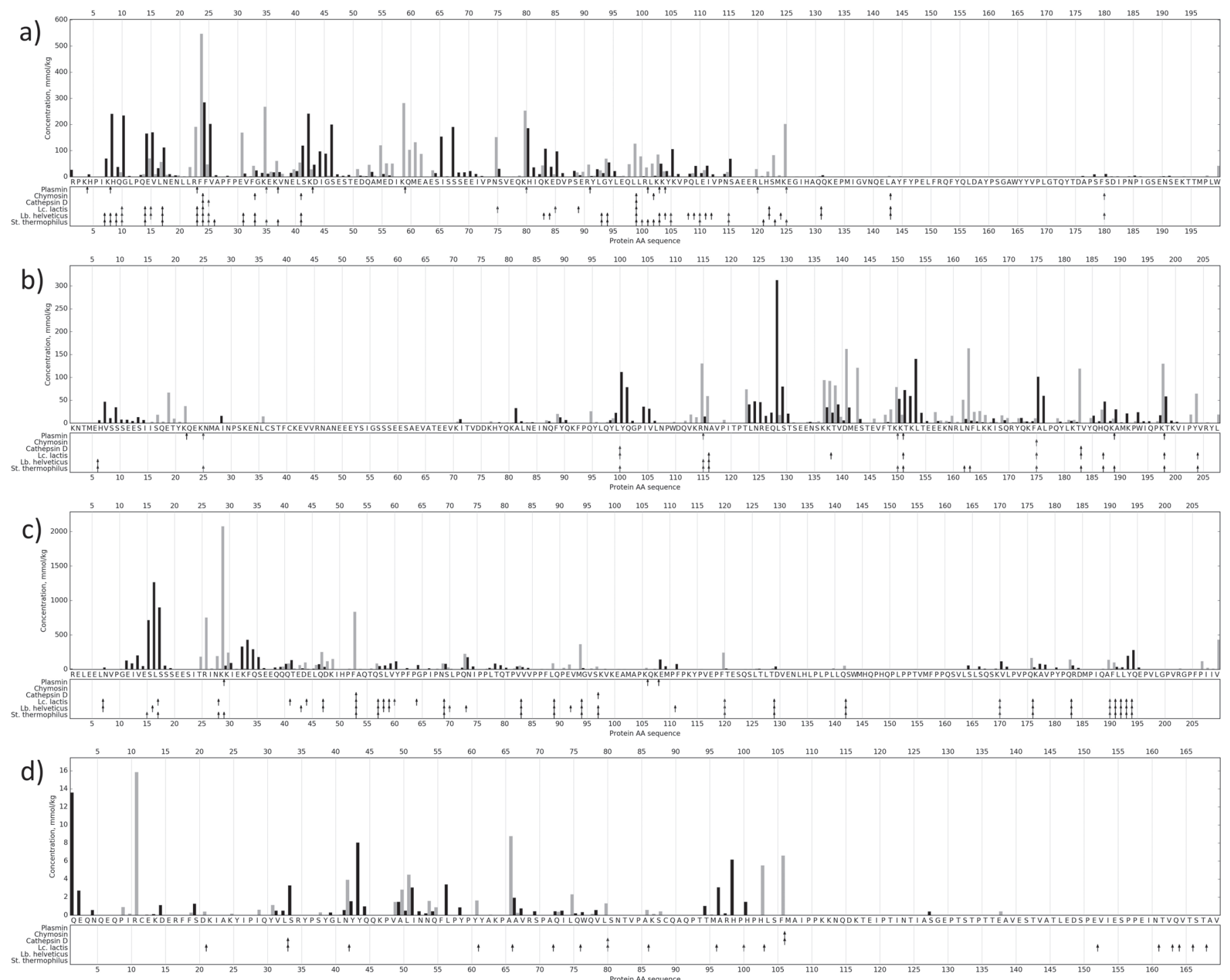

Figure 5. Cleavage sites plotted on the $\alpha_{\mathrm{S1}^{-}} \mathrm{CN}(\mathrm{a}), \alpha_{\mathrm{S} 2^{-}} \mathrm{CN}(\mathrm{b}), \beta-\mathrm{CN}(\mathrm{c})$, and $\kappa-\mathrm{CN}$ (d) sequences in the 8-mo-old Old Saare cheese (based on all 3,040 water-soluble peptides determined by liquid chromatography-MS/MS). Black bars indicate summed estimated molar concentrations of the AA at the N-terminal and grey bars at the C-terminal ends of all identified peptides. Important cleavages found in this study and assigned to known proteolytic agents: plasmin (Le Bars and Gripon, 1989; McSweeney et al., 1993b; Fox and McSweeney, 1996), chymosin (McSweeney et al., 1993a; Exterkate et al., 1997), cathepsin D (Larsen et al., 1996), cell envelope proteinases of Lactococcus lactis (Monnet et al., 1992; Exterkate and Alting, 1993; Kunji et al., 1996), CEP of Lactobacillus helveticus (Kunji et al., 1996; Sadat-Mekmene et al., 2011), and the proteolytic system of Streptococcus thermophilus (Miclo et al., 2012) are marked with the arrows. The degradation of the C-terminal part of $\kappa$-CN f106-169 can be clearly seen only during the first month of ripening; accordingly, the arrows shown in the C-terminus of the protein indicate prominent cleavage sites determined at the beginning of the ripening. Results represent the mean values of duplicated samples from each of 2 cheesemaking trials $(n=4)$.

main metabolically active species in Old Saare cheese (L. Blank, TUT, Tallinn, Estonia, personal communication). Thus, the thermophilic bacteria were likely to play an essential role in the hydrolysis of the $\beta-\mathrm{CN}$ during the ripening of Old Saare cheese. Three phosphopeptides, $\beta$-CN f15/16/17-28, accumulated very fast during the ripening and comprised in terms of their molar abundance approximately $20 \%$ of $\beta$-CN-derived water-soluble peptides in cheese samples ripened for 8 mo (Table 3). These peptides could be generated from $\beta-\mathrm{CN}$ f1/7-28 by the action of both mesophilic and thermophilic starters on $\mathrm{Glu}_{14}-\mathrm{Ser}_{15}$ (St. thermophilus; Miclo et al., 2012), $\operatorname{Ser}_{15}-\operatorname{Leu}_{16}$ (Lb. helveticus; Kunji et al., 1996; Sadat-Mekmene et al., 2011), and $\mathrm{Leu}_{16^{-}}$ $\operatorname{Ser}_{17}$ (Lc. lactis and St. thermophilus; Kunji et al., 1996; Miclo et al., 2012). Besides, we observed a substantial cleavage of the bond $\mathrm{Asn}_{27}-\mathrm{Lys}_{28}$ (Figure 5c), which has been previously reported to be susceptible for 
splitting by CEP of Lc. lactis (Kunji et al., 1996) as well as St. thermophilus proteolytic system (Miclo et al., 2012). The noticeable formation of several peptides (f11/12/13/15/16/17-28) differing in length by 1 or 2 AA residues in the $\mathrm{N}$-terminal end and produced by successive degradation of $\beta-\mathrm{CN} \mathrm{f} 7-28$, whereas the C-terminus remains the same (Table 3), may indicate significant activity of aminopeptidases in the cheese, though the endopeptidases of LAB may also be involved (Tan et al., 1993). However, the cleavage patterns of $\beta-\mathrm{CN}$, showing that the N-terminal AA of peptides were in the consecutive positions in the region f11-17, and lacking the C-terminal AA of other (complementary) peptides in the same positions (Figure 5c), clearly supported the assumption of the action of aminopeptidases in the formation of these peptides. In addition, we observed a significant cleavage of $\mathrm{Arg}_{25}-\mathrm{Ile}_{26}$ bond (Figure 5c); unfortunately, we did not find the data on the origin of this cleavage in the literature. It is noteworthy that among different peptides located in the region $\beta$-CN f1-28, especially phosphorylated ones with the phosphate groups at positions $\mathrm{Ser}_{15}, \mathrm{Ser}_{17}, \mathrm{Ser}_{18}$, $\mathrm{Ser}_{19}, \mathrm{Ser}_{22}$, and $\mathrm{Thr}_{24}$, appeared in the highest amounts during the ripening as noted above. Low activity of acid phosphatase (an enzyme that determines the degree of phosphorylation of caseins and their hydrolysis products) has been shown to inhibit degradation of phosphopeptides in cheese (Hynek et al., 2002). Hence, the high abundance of phosphopeptides in Old Saare is in accordance with the observations made in earlier studies that multiphosphorylated casein peptides are much more resistant to further hydrolysis by LAB peptidases than other fragments (Hynek et al., 2002), and that especially the phosphopeptides arising from $\beta-\mathrm{CN}$ phosphoserine-rich region f15-22 tend to accumulate during cheese ripening (Ferranti et al., 1997a; Deutsch et al., 2000; Lund and Ardö, 2004).

The peptides from the strongly negatively charged hydrophilic region of $\beta$-CN f29-52 were also present in substantial amounts in Old Saare cheese (Figure 4c, Table 3), comprising approximately 16 to $24 \%$ of $\beta$-CN derived water-soluble peptides depending on the ripening time. Most of the peptides were present in the highest amount at 3 to 4 mo of ripening. The Nterminus of these peptides supposedly was the result of plasmin cleavage followed by a sequential action of aminopeptidases released from the lyzing LAB. The C-terminus of the peptides from this region was determined presumably by the hydrolysis of the bond $\mathrm{Phe}_{52}-\mathrm{Ala}_{53}$ either by CEP of Lc. lactis (Kunji et al., 1996) and Lb. helveticus strains (Sadat-Mekmene et al., 2011), by proteolytic system of some St. thermophilus strains (Miclo et al., 2012), or by indigenous milk proteinase cathepsin D (Larsen et al., 1996). We also detected extensive cleavage at other known preferable in vitro sites of CEP of lactococci $\left(\mathrm{Gln}_{40^{-}} \mathrm{Thr}_{41}, \mathrm{Asp}_{43^{-}}\right.$ $\mathrm{Glu}_{44}, \mathrm{Gln}_{46}-\mathrm{Asp}_{47}$; Kunji et al., 1996) and Lb. helveticus $\left(\mathrm{Glu}_{42}-\mathrm{Asp}_{43}, \mathrm{Gln}_{46}-\mathrm{Asp}_{47}\right.$; Kunji et al., 1996; SadatMekmene et al., 2011; Figure 5c). Similarly to the case of previous region $\beta-\mathrm{CN}$ f1-28, the peptides from $\beta-\mathrm{CN}$ f29-52 detected at the highest amounts (i.e., peptides f29/30/32/33/34/35/40/41-52), belonged to potential phosphopeptides with phosphorylated $\mathrm{Ser}_{35}$ and $\mathrm{Thr}_{41}$ (Table 3).

The third group of peptides generated from $\beta-\mathrm{CN}$ at high amounts, especially in the 1- to 4-mo-old cheese, arose from a hydrophobic region f53-93 (Figure 4c, Table 3). The region $\beta-\mathrm{CN}$ f53-93 contained numerous cleavage sites of CEP of lactococci, overlapping with the preferable hydrolysis sites of the enzymes of $L b$. helveticus and St. thermophilus reported in the literature [e.g., $\mathrm{Gln}_{56}-\mathrm{Ser}_{57}, \mathrm{Asn}_{68}-\mathrm{Ser}_{69}, \mathrm{Val}_{82^{2}}-\mathrm{Val}_{83}, \mathrm{Glu}_{88}-\mathrm{Val}_{89}$, Met $_{93}$-Gly $_{94}$ (Kunji et al., 1996; Sadat-Mekmene et al., 2011; Miclo et al., 2012)], which we found significantly cleaved in our study (Figure 5c). We observed a number of additional possible cleavages of Lb. helveticus [i.e., $\mathrm{Gln}_{72}-\mathrm{Asn}_{73}$ and $\mathrm{Glu}_{91}-\mathrm{Val}_{92}$ (Sadat-Mekmene et al., 2011)]; peptides originating from the hydrolysis of respective bonds were present in notable amounts throughout Old Saare ripening (Table 3). Simultaneous accompanying activity of aminopeptidases on the regions $\beta$-CN f57-60 and f77-80 was also observed (Figure 5c). Many peptides resulting from aforementioned cleavages ( $\beta-\mathrm{CN}$ f60-72, f69-93, and f73-91/93/96) were present in high concentrations in Old Saare cheese from the very beginning of ripening (Table 3 ).

The C-terminal part of $\beta$-CN released a relatively low amount of peptides (Figure 4c). However, the cumulative concentrations of peptides from the regions $\beta-\mathrm{CN}$ f94-120 and f170-209 were similar to those from $\alpha_{S_{1}}-\mathrm{CN}$ and $\alpha_{\mathrm{S}^{-}} \mathrm{CN}$ parts of the sequences with the highest abundance of peptides (Figure 4). Proteolytic profiles of the regions $\beta-\mathrm{CN}$ f94-120 and f170-209 may be characterized by the primary action of cathepsin D supported by a possible action of proteolytic enzymes of Lb. helveticus and St. thermophilus on the bond $\mathrm{Ser}_{96}$-Lys $_{97}$ (Larsen et al., 1996; Sadat-Mekmene et al., 2011; Miclo et al., 2012), as well as by the initial activity of plasmin on the bonds $\mathrm{Lys}_{105}-\mathrm{Gln}_{106}$ and $\mathrm{Lys}_{107^{-}}$ $\mathrm{Glu}_{108}$ (Fox and McSweeney, 1996). We also found a pronounced cleavage at numerous in vitro indicated hydrolysis sites of the proteolytic enzymes of both mesophilic and thermophilic starters, $\mathrm{Phe}_{110}-\mathrm{Pro}_{111}$, Phe $_{119}-\mathrm{Thr}_{120}, \mathrm{Lys}_{169}-\mathrm{Val}_{170}, \mathrm{Gln}_{175} \mathrm{Lys}_{176}, \mathrm{Gln}_{182}-\mathrm{Arg}_{183}$, Ala $_{189}-\mathrm{Phe}_{190}, \mathrm{Phe}_{190}-\mathrm{Leu}_{191}, \mathrm{Leu}_{191}-\mathrm{Leu}_{192}, \mathrm{Leu}_{192}-\mathrm{Tyr}_{193}$, and $\mathrm{Tyr}_{193} \mathrm{Gln}_{194}$ (Kunji et al., 1996; Sadat-Mekmene et al., 2011; Miclo et al., 2012; Figure 5c). The abovementioned cleavages led to the formation of the follow- 
Table 3. List of the most abundant peptides ( $\mu$ mol $/ \mathrm{kg}$ of cheese) derived from $\beta-\mathrm{CN}, \alpha_{\mathrm{S} 1^{-}} \mathrm{CN}$, and $\alpha_{\mathrm{S} 2}$-CN detected in water-soluble extract of Old Saare by liquid chromatography-MS/MS

Ripening time

\begin{tabular}{|c|c|c|c|c|c|c|}
\hline Fragment & $1 \mathrm{~d}$ & $1 \mathrm{mo}$ & $3 \mathrm{mo}$ & $5 \mathrm{mo}$ & $8 \mathrm{mo}$ & Groups \\
\hline$\beta-\mathrm{CN}$ f7-28 & $26.8 \pm 16.0$ & $20.2 \pm 12.1$ & $44.0 \pm 21.6$ & $34.1 \pm 16.3$ & $20.4 \pm 7.8$ & 3 \\
\hline$\beta-\mathrm{CN}$ f11-28 & $0.6 \pm 0.4$ & $70.4 \pm 39.2$ & $261.6 \pm 178.6$ & $130.8 \pm 63.9$ & $99.8 \pm 18.5$ & 3 \\
\hline$\beta-\mathrm{CN}$ f12-28 & $1.0 \pm 0.7$ & $111.3 \pm 40.2$ & $180.2 \pm 49.6$ & $120.4 \pm 82.5$ & $59.9 \pm 22.1$ & 3 \\
\hline$\beta-C N$ f12-29 & $0.3 \pm 0.3$ & $13.2 \pm 6.2$ & $54.5 \pm 55.5$ & $36.0 \pm 19.2$ & $18.6 \pm 11.1$ & 3 \\
\hline$\beta-C N$ f13-28 & $0.0 \pm 0.0$ & $9.6 \pm 4.7$ & $122.1 \pm 46.4$ & $134.9 \pm 47.0$ & $188.2 \pm 56.8$ & 4 \\
\hline$\beta-\mathrm{CN}$ f15-27 & $0.8 \pm 0.4$ & $6.3 \pm 2.5$ & $30.7 \pm 23.5$ & $28.2 \pm 30.1$ & $20.2 \pm 20.9$ & 3 \\
\hline$\beta-\mathrm{CN}$ f15-28 & $2.4 \pm 2.2$ & $51.4 \pm 41.5$ & $499.5 \pm 393.9$ & $444.6 \pm 424.6$ & $464.0 \pm 420.8$ & 3 \\
\hline$\beta-C N$ f $15-29$ & $0.1 \pm 0.1$ & $6.2 \pm 5.7$ & $129.6 \pm 139.0$ & $111.8 \pm 125.4$ & $107.5 \pm 117.2$ & 3 \\
\hline$\beta-C N$ f16-24 & $0.1 \pm 0.1$ & $1.2 \pm 0.1$ & $34.7 \pm 7.3$ & $70.7 \pm 25.9$ & $181.8 \pm 54.1$ & 3 \\
\hline$\beta-C N$ f16-25 & $0.3 \pm 0.3$ & $16.4 \pm 2.4$ & $151.8 \pm 40.1$ & $258.7 \pm 16.1$ & $382.0 \pm 26.9$ & 3 \\
\hline$\beta-\mathrm{CN}$ f16-27 & $1.5 \pm 0.5$ & $37.9 \pm 13.4$ & $112.1 \pm 47.6$ & $74.1 \pm 25.4$ & $63.0 \pm 18.9$ & 3 \\
\hline$\beta-\mathrm{CN}$ f16-28 & $3.0 \pm 1.8$ & $74.0 \pm 22.1$ & $477.6 \pm 149.1$ & $522.1 \pm 83.3$ & $631.8 \pm 178.4$ & 3 \\
\hline$\beta-\mathrm{CN}$ f29-46 & $8.3 \pm 2.7$ & $6.2 \pm 2.5$ & $17.7 \pm 6.5$ & $10.4 \pm 2.7$ & $8.6 \pm 2.5$ & 3 \\
\hline$\beta-\mathrm{CN}$ f29-52 & $42.7 \pm 26.1$ & $51.2 \pm 31.1$ & $53.0 \pm 24.5$ & $55.7 \pm 36.4$ & $23.8 \pm 22.0$ & 1 \\
\hline$\beta-\mathrm{CN}$ f30-36 & $16.9 \pm 7.4$ & $6.7 \pm 4.5$ & $2.2 \pm 1.5$ & $0.3 \pm 0.7$ & $1.3 \pm 0.8$ & 1 \\
\hline$\beta-C N$ f30-40 & $20.2 \pm 3.9$ & $4.6 \pm 0.5$ & $9.2 \pm 3.0$ & $6.8 \pm 5.1$ & $6.1 \pm 2.9$ & 1 \\
\hline$\beta-\mathrm{CN}$ f30-46 & $7.9 \pm 3.4$ & $7.2 \pm 3.3$ & $14.2 \pm 5.3$ & $9.6 \pm 1.1$ & $10.9 \pm 1.8$ & 3 \\
\hline$\beta-\mathrm{CN}$ f30-52 & $17.2 \pm 8.6$ & $54.6 \pm 16.3$ & $77.7 \pm 20.3$ & $68.4 \pm 19.8$ & $47.4 \pm 28.5$ & 3 \\
\hline$\beta-\mathrm{CN}$ f32-40 & $4.3 \pm 4.9$ & $17.7 \pm 6.7$ & $38.4 \pm 15.0$ & $24.3 \pm 15.9$ & $27.2 \pm 17.0$ & 2 \\
\hline$\beta-\mathrm{CN}$ f32-43 & $5.9 \pm 2.6$ & $21.0 \pm 3.2$ & $27.2 \pm 9.9$ & $20.1 \pm 1.7$ & $30.0 \pm 19.9$ & 3 \\
\hline$\beta-\mathrm{CN}$ f32-46 & $5.7 \pm 2.5$ & $27.7 \pm 15.0$ & $68.3 \pm 18.6$ & $53.0 \pm 22.1$ & $54.2 \pm 12.3$ & 3 \\
\hline$\beta-\mathrm{CN}$ f32-52 & $10.7 \pm 2.3$ & $52.5 \pm 9.3$ & $68.4 \pm 50.2$ & $87.1 \pm 32.1$ & $78.8 \pm 58.9$ & 3 \\
\hline$\beta-\mathrm{CN}$ f33-40 & $6.2 \pm 2.3$ & $16.6 \pm 3.6$ & $62.8 \pm 16.1$ & $35.8 \pm 28.5$ & $51.6 \pm 24.3$ & 3 \\
\hline$\beta-\mathrm{CN}$ f33-42 & $5.1 \pm 2.5$ & $15.9 \pm 4.8$ & $43.0 \pm 6.1$ & $28.9 \pm 7.8$ & $39.1 \pm 6.8$ & 3 \\
\hline$\beta-\mathrm{CN}$ f33-43 & $7.4 \pm 3.1$ & $25.2 \pm 5.1$ & $52.1 \pm 11.4$ & $36.3 \pm 9.0$ & $54.0 \pm 22.8$ & 3 \\
\hline$\beta-\mathrm{CN}$ f33-46 & $5.6 \pm 1.9$ & $42.4 \pm 3.6$ & $66.6 \pm 9.8$ & $44.0 \pm 28.4$ & $72.4 \pm 14.1$ & 3 \\
\hline$\beta-\mathrm{CN} \mathrm{f} 44-52$ & $20.4 \pm 3.0$ & $30.3 \pm 3.9$ & $8.9 \pm 3.6$ & $9.4 \pm 1.3$ & $9.9 \pm 1.2$ & 2 \\
\hline$\beta-\mathrm{CN}$ f $45-52$ & $3.8 \pm 2.7$ & $15.6 \pm 3.2$ & $13.2 \pm 9.6$ & $7.7 \pm 2.1$ & $13.2 \pm 6.5$ & 2 \\
\hline$\beta-\mathrm{CN}$ f46-52 & $0.6 \pm 0.4$ & $5.5 \pm 1.0$ & $81.0 \pm 17.8$ & $26.0 \pm 32.2$ & $76.3 \pm 5.8$ & 3 \\
\hline$\beta-\mathrm{CN} \mathrm{f} 47-52$ & $0.3 \pm 0.2$ & $3.5 \pm 1.2$ & $55.1 \pm 9.3$ & $22.4 \pm 27.0$ & $39.4 \pm 4.2$ & 3 \\
\hline$\beta-\mathrm{CN}$ f $57-72$ & $3.8 \pm 3.1$ & $31.9 \pm 12.1$ & $35.7 \pm 7.3$ & $16.4 \pm 3.5$ & $15.3 \pm 1.1$ & 3 \\
\hline$\beta-\mathrm{CN}$ f58-68 $\left(\mathrm{A}^{2}, \mathrm{~A}^{3}\right)$ & $2.8 \pm 2.5$ & $31.6 \pm 9.6$ & $49.2 \pm 13.1$ & $22.8 \pm 2.2$ & $16.6 \pm 3.8$ & 3 \\
\hline$\beta-\mathrm{CN}$ f58-72 $\left(\mathrm{A}^{1}, \mathrm{~B}\right)$ & $3.4 \pm 2.8$ & $36.5 \pm 12.4$ & $28.2 \pm 7.9$ & $16.0 \pm 3.5$ & $13.1 \pm 1.8$ & 2 \\
\hline$\beta-\mathrm{CN}$ f59-72 (A $\left.\mathrm{A}^{1}, \mathrm{~B}\right)$ & $3.8 \pm 2.8$ & $41.0 \pm 17.7$ & $60.3 \pm 9.4$ & $21.3 \pm 6.5$ & $15.6 \pm 8.5$ & 2 \\
\hline$\beta-\mathrm{CN}$ f59-68 $\left(\mathrm{A}^{2}, \mathrm{~A}^{3}\right)$ & $4.3 \pm 3.7$ & $52.0 \pm 14.2$ & $60.5 \pm 11.8$ & $29.2 \pm 3.2$ & $23.0 \pm 5.5$ & 2 \\
\hline$\beta-\mathrm{CN}$ f60-68 $\left(\mathrm{A}^{2}, \mathrm{~A}^{3}\right)$ & $16.5 \pm 10.4$ & $45.2 \pm 15.1$ & $42.9 \pm 9.4$ & $12.1 \pm 10.1$ & $8.0 \pm 3.4$ & 2 \\
\hline$\beta-\mathrm{CN}$ f60-69 $\left(\mathrm{A}^{1}, \mathrm{~B}\right)$ & $17.4 \pm 7.5$ & $27.7 \pm 6.0$ & $16.4 \pm 6.1$ & $9.4 \pm 3.5$ & $10.1 \pm 2.6$ & 2 \\
\hline$\beta-\mathrm{CN}$ f60-72 $\left(\mathrm{A}^{1}, \mathrm{~B}\right)$ & $63.4 \pm 35.2$ & $133.8 \pm 44.7$ & $108.3 \pm 32.5$ & $42.0 \pm 11.2$ & $60.8 \pm 25.6$ & 2 \\
\hline$\beta-\mathrm{CN} \mathrm{f60-72}\left(\mathrm{A}^{2}, \mathrm{~A}^{3}\right)$ & $11.1 \pm 4.6$ & $23.0 \pm 3.9$ & $18.8 \pm 12.2$ & $7.9 \pm 8.1$ & $4.7 \pm 6.9$ & 1 \\
\hline$\beta-\mathrm{CN}$ f62-72 $\left(\mathrm{A}^{1}, \mathrm{~B}\right)$ & $11.2 \pm 2.8$ & $24.5 \pm 9.2$ & $21.6 \pm 8.7$ & $8.0 \pm 1.7$ & $11.7 \pm 2.0$ & 2 \\
\hline$\beta-\mathrm{CN}$ f64-72 $\left(\mathrm{A}^{1}, \mathrm{~B}\right)$ & $30.8 \pm 2.4$ & $175.4 \pm 36.0$ & $131.9 \pm 35.3$ & $50.2 \pm 3.8$ & $56.8 \pm 9.0$ & 2 \\
\hline$\beta-\mathrm{CN}$ f69-93 & $49.7 \pm 9.8$ & $55.3 \pm 8.7$ & $97.4 \pm 30.0$ & $68.3 \pm 11.9$ & $65.6 \pm 10.4$ & 3 \\
\hline$\beta-\mathrm{CN}$ f72-93 & $1.0 \pm 1.0$ & $30.6 \pm 8.9$ & $47.7 \pm 29.4$ & $12.3 \pm 3.9$ & $15.6 \pm 15.0$ & 2 \\
\hline$\beta-\mathrm{CN}$ f73-91 & $28.6 \pm 5.8$ & $67.8 \pm 8.3$ & $60.3 \pm 21.7$ & $37.6 \pm 14.1$ & $25.2 \pm 10.7$ & 2 \\
\hline$\beta-\mathrm{CN}$ f73-93 & $103.0 \pm 32.5$ & $145.3 \pm 23.9$ & $191.1 \pm 28.4$ & $124.9 \pm 23.5$ & $109.3 \pm 31.8$ & 2 \\
\hline
\end{tabular}


Table 3 (Continued). List of the most abundant peptides ( $\mu \mathrm{mol} / \mathrm{kg}$ of cheese) derived from $\beta-\mathrm{CN}, \alpha_{\mathrm{S1}}{ }^{-\mathrm{CN}}$, and $\alpha_{\mathrm{S} 2^{-}} \mathrm{CN}$ detected in watersoluble extract of Old Saare by liquid chromatography-MS/MS

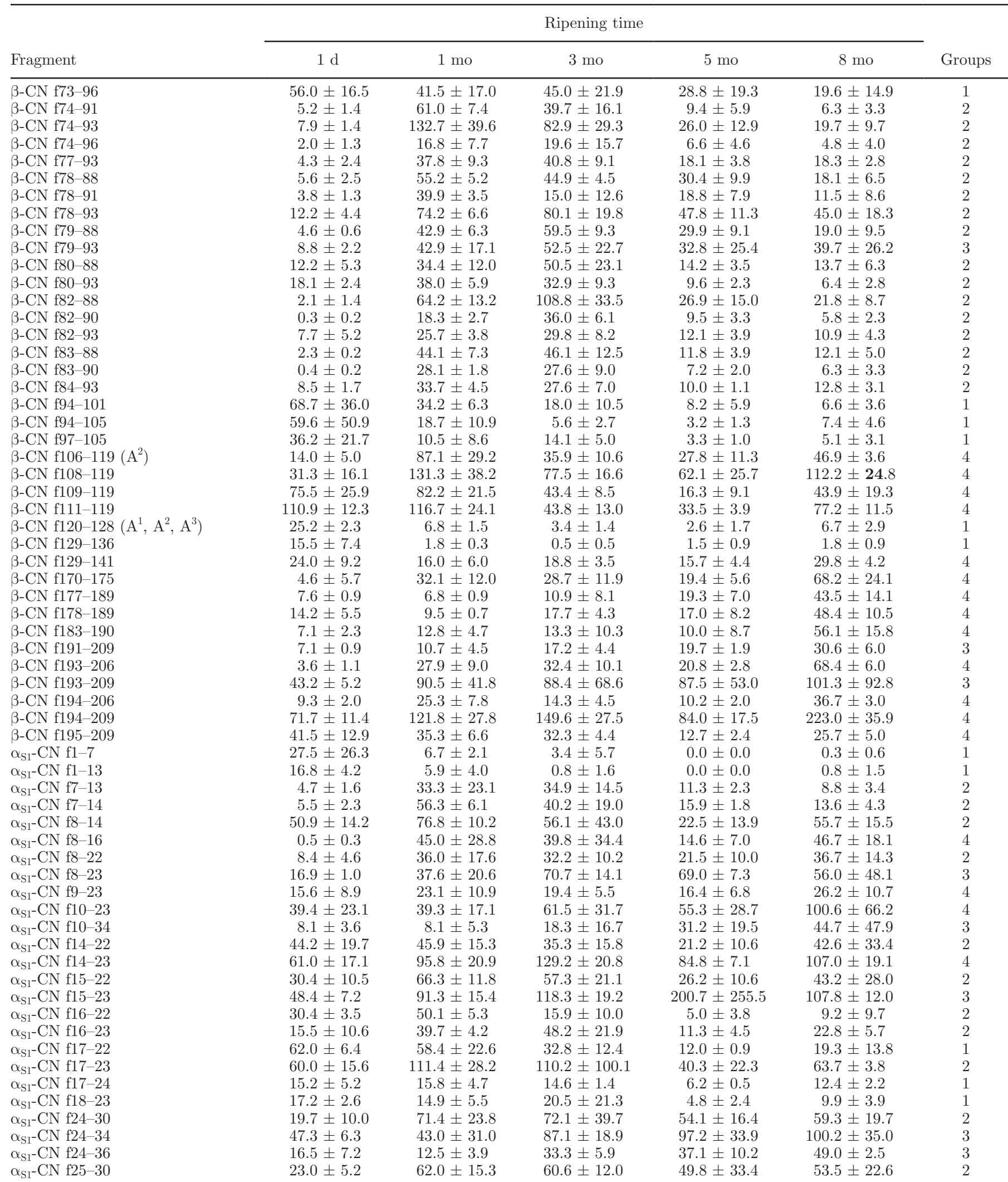


Table 3 (Continued). List of the most abundant peptides ( $\mu \mathrm{mol} / \mathrm{kg}$ of cheese) derived from $\beta$-CN, $\alpha_{\mathrm{S1}^{-}} \mathrm{CN}$, and $\alpha_{\mathrm{S} 2^{-}} \mathrm{CN}$ detected in watersoluble extract of Old Saare by liquid chromatography-MS/MS ${ }^{1}$

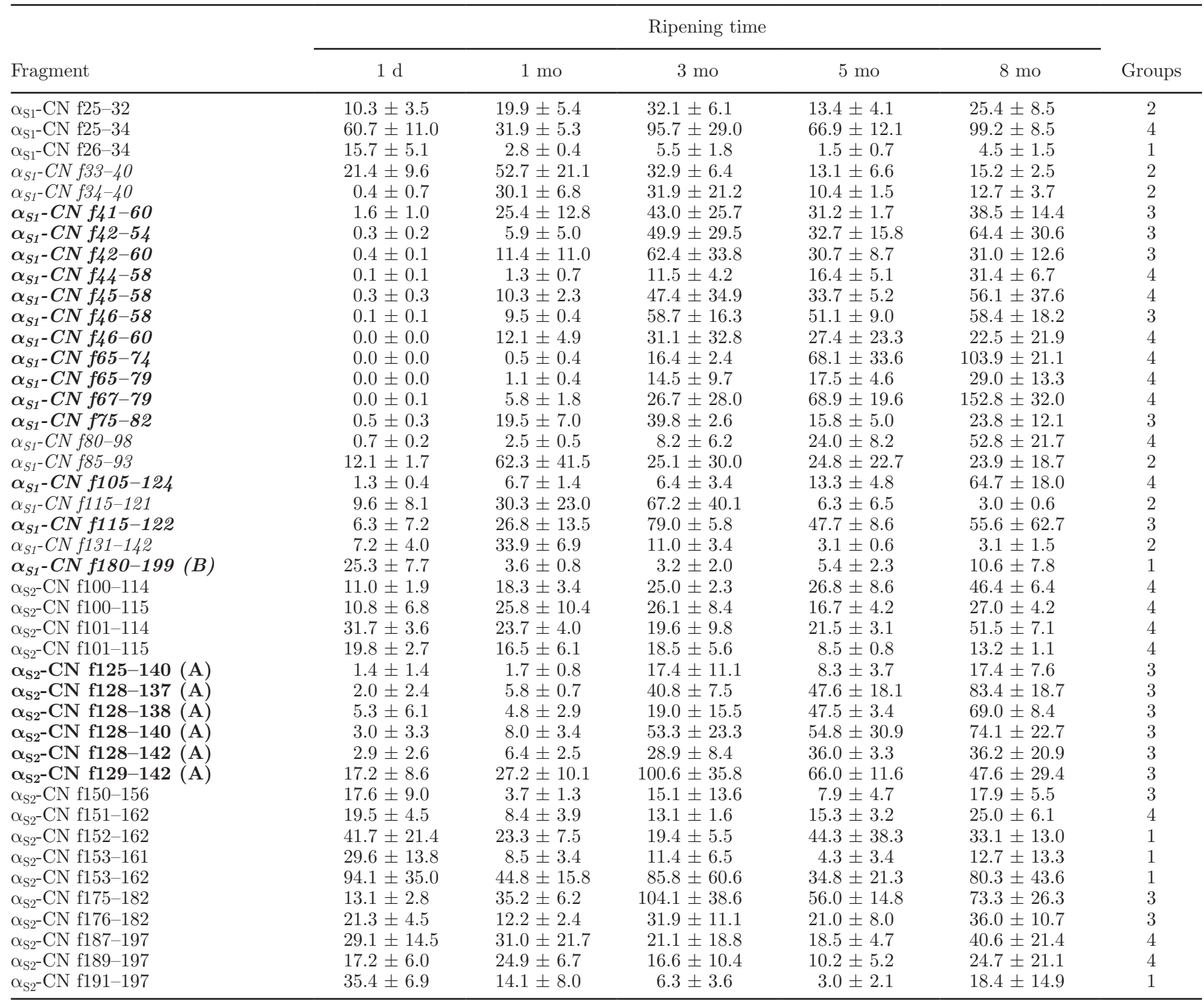

${ }^{1}$ Values are the means of estimated concentrations of duplicated samples from each of 2 cheesemaking trials $($ mean \pm SD, $\mathrm{n}=4)$. Potential phosphopeptides determined by MaxQuant (version 1.5.2.8; Cox and Mann, 2008) search based on MS/MS spectra are marked in bold. The MaxQuant search was performed against casein sequences of the following genetic variants: $\mathrm{A}^{1}, \mathrm{~A}^{2}, \mathrm{~A}^{3}$, and $\mathrm{B}$ for $\beta-\mathrm{CN} ; \mathrm{A}, \mathrm{B}$, and $\mathrm{C}$ for $\alpha_{\mathrm{S1}}-\mathrm{CN}$; and $\mathrm{A}$ and $\mathrm{C}$ for $\alpha_{\mathrm{S}_{2}} \mathrm{CN}$. The peptides marked in italics could be derived from the genetic variant $\mathrm{A}$ of $\alpha_{\mathrm{S} 1^{-}} \mathrm{CN}$ with the different index numbers of AA, as AA 14 to 26 are deleted from the sequence. Numbers in the last column refer to the groups showing similar evolutionary trends of peptides according to the clustering analysis.

ing peptides determined in considerable amounts: $\beta-\mathrm{CN}$ f106/108/111-119 and f193/194-206/209 (Table 3).

A very low concentration of peptides was released from the region $\beta-\mathrm{CN}$ f120-170 (Figure 4c). This was in agreement with the observation by Gagnaire et al. (2001), who have indicated the absence of peptides among the most abundant ones in even a wider region of $\beta$-CN sequence (f108-192) in the case of Emmental cheese. Gagnaire et al. (2001) have explained the lack of hydrolysis of the preferred in vitro cleavage sites by the difference of the physicochemical conditions in cheese changing the specificity of proteolytic enzymes and the different accessibility of cleavage sites of caseins in cheese protein matrix in comparison with in vitro conditions, as proposed by Exterkate et al. (1997). Nevertheless, the full analysis of MS/MS profiles in our study showed that peptides were released from all the regions of the sequence of $\beta-\mathrm{CN}$ including the region 
f120-170 (Supplemental Figure S1c, https://doi.org/10 $.3168 /$ jds.2017-12944). The latter region did not contain plasmin hydrolysis sites, but has been shown to include some in vitro cleavage sites of bacterial proteases [e.g., $\mathrm{Thr}_{128}-\mathrm{Asp}_{129}$ and $\mathrm{Gln}_{141}$ Ser $_{142}$ (Kunji et al., 1996; Sadat-Mekmene et al., 2011; Miclo et al., 2012)], which were found cleaved in Old Saare cheese (Figure 5c). We even determined a few peptides (i.e., $\beta$-CN f120-128 and f129-141), formed in high concentrations presumably in the result of the cleavage of aforementioned sites (Table 3).

Several peptides of $\beta$-CN shown to have bitter taste in Gouda cheese (Toelstede and Hofmann, 2008) were present also in Old Saare cheese in substantial amounts (e.g., peptides f59-68, f60-68/69, and f193-209). The latter peptide was detected in the highest concentration in comparison with the other bitter peptides and accumulated in the end of 8 mo ripening. In contrast, the content of the former peptides was the highest at the beginning of ripening, and they were degraded afterward.

$\alpha_{S 1^{-}}$CN-Derived Small Peptides. In case of $\alpha_{S 1^{-}}$ $\mathrm{CN}$, the majority of peptides arose from the N-terminal part of the protein, f1-124 (Figure 4a). Fewer peptides in much lower amounts originated from the C-terminal part of the sequence, f125-199 (Supplemental Figure S1a, https://doi.org/10.3168/jds.2017-12944).

The peptides from the region f1-23 comprised approximately $49 \%$ of all peptides formed from $\alpha_{\mathrm{S} 1}-\mathrm{CN}$ in the 1-d-old cheese. Further, their relative content decreased gradually up to $23 \%$ in the 4 -mo-old cheese, remaining rather constant until the end of the ripening. It means that the $\alpha_{\mathrm{S}_{1}} \mathrm{CN}$ f1-23 region was preferably hydrolyzed in Old Saare cheese compared with the rest of the protein sequence at the beginning of ripening, similarly to the ripening of Emmental (Gagnaire et al., 2001; Sadat-Mekmene et al., 2013). The high content of peptides from region f1-23 (Figure 4a) could be considered as an indication of high activity of chymosin in proteolysis of $\alpha_{\mathrm{S}_{1}}-\mathrm{CN}$, cleaving the preferable bond $\mathrm{Phe}_{23}-\mathrm{Phe}_{24}$, and subsequent hydrolysis by the microbial enzymes of the resulting peptides (Fox and McSweeney, 1996). However, taking into account the presumably high thermal inactivation of chymosin during the cooking of cheese grains, the initial formation of $\alpha_{\mathrm{S} 1}-\mathrm{CN}$ f1-23 can be assigned also to the action of cathepsin D (Larsen et al., 1996). Indeed, a more detailed analysis of the cleavage patterns supported the assumption that the indigenous milk proteinases (cathepsin D and plasmin) may participate in the sequential hydrolysis of the $\mathrm{N}$-terminus of $\alpha_{\mathrm{S} 1}-\mathrm{CN}$ (Figure 5a). Thus, we assigned the production of particular abundant peptides (e.g., f1-7 and f8-22), and the cutting in the N-terminus of the peptides f25-30/32/34 (Table 3), to an evident hydrolysis of the possible sites of plasmin: $\mathrm{Lys}_{3}-\mathrm{His}_{4}$, $\mathrm{Lys}_{7}-\mathrm{His}_{8}$, and $\mathrm{Arg}_{22}-\mathrm{Phe}_{23}$ (McSweeney et al., 1993b), as well as of another preferable bond of cathepsin D: $\mathrm{Phe}_{24}-\mathrm{Val}_{25}$ (Larsen et al., 1996).

We observed a high total concentration of released peptides from the N-terminal region of $\alpha_{\mathrm{S}_{1}} \mathrm{CN}$, f1-40, at the beginning of the ripening, followed by a subsequent gradual increase of their contents (Figure 4a). However, only few peptides from this region among the numerous abundant ones could be characterized by a clear accumulating trend by the end of the ripening (i.e., f10-23/34 and f24-34/36; Table 3 ). The majority of the peptides revealed a fluctuating behavior indicating their simultaneous and unbalanced production and digestion to smaller degradation products during ripening. The oligopeptides f1-22/23/24, originating from primary hydrolysis of $\alpha_{\mathrm{S}_{1}}$-CN by plasmin, cathepsin $\mathrm{D}$, and residual chymosin, could have been degraded to smaller fragments by the cleavage of the bonds $\mathrm{Gln}_{9}-\mathrm{Gly}_{10}$, $\mathrm{Gln}_{13}-\mathrm{Glu}_{14}, \mathrm{Gln}_{14}-\mathrm{Val}_{15}$, and $\mathrm{Leu}_{16}-\mathrm{Asn}_{17}$ (Figure 5a) by CEP of Lc. lactis (Exterkate and Alting, 1993), resulting in the liberation of peptides f1-13, f10-23, f14/15$22 / 23$, and $17-22 / 23 / 24$ in high amounts already in the 1-d-old cheese (Table 3 ). The latter peptides were likely degraded further in Old Saare cheese by the proteolytic enzymes of starter bacteria containing also thermophilic in addition to mesophilic strains, differently from cheeses produced only with mesophilic starters (e.g., Cheddar and Västerbottenost), where the accumulation of peptides released by CEP of lactococci has been reported (Broadbent et al., 2002; Rehn et al., 2010). The $\mathrm{CEP}$ of $L b$. helveticus have shown broader proteolytic activity on the N-terminus of $\alpha_{S_{1}}-\mathrm{CN}$ compared with CEP of Lc. lactis, acting on bonds $\mathrm{Ile}_{6}-\mathrm{Lys}_{7}, \mathrm{Lys}_{7}-\mathrm{His}_{8}$, $\mathrm{His}_{8}-\mathrm{Gln}_{9}$ in addition to all reported lactococcal preferable cleavage sites (Sadat-Mekmene et al., 2011). The proteolytic system of St. thermophilus could also have been involved in the hydrolysis of these bonds (Miclo et al., 2012). Furthermore, the proteolytic enzymes of Lb. helveticus and St. thermophilus have been shown to hydrolyze also the positions $\mathrm{Glu}_{30}-\mathrm{Val}_{31}, \mathrm{Phe}_{32}-\mathrm{Gly}_{33}$, and $\mathrm{Leu}_{40}-\mathrm{Ser}_{41}$ (Sadat-Mekmene et al., 2011; Miclo et al., 2012), competing with chymosin for the latter 2 bonds (Exterkate et al., 1997). Accordingly, we associated the extensive cleavage of the aforementioned sites (Figure 5a) and the formation of corresponding small peptides $\mathrm{f7}-13 / 14$ and the C-terminus of $\mathrm{f} 24 / 25$ $30, \mathrm{f} 25-32, \mathrm{f} 33 / 34-40$ to a high proteolytic activity of a thermophilic starter cultures found in higher relative abundance in Old Saare cheese (L. Blank, TUT, Tallinn, Estonia, personal communication). Additionally, we may relate the location of C-termini of the abundant 
peptides f10/24/25/26-34 and f24-36 (Table 3) to the action of plasmin on the bonds $\mathrm{Lys}_{34}-\mathrm{Glu}_{35}$ and $\mathrm{Lys}_{36^{-}}$ $\mathrm{Val}_{37}$ (McSweeney et al., 1993b).

The next parts of the sequence, $\alpha_{\mathrm{S}_{1}} \mathrm{CN}$ f41-63 and f65-79 (Figure 4a), containing phosphorylated sites at $\mathrm{Ser}_{41}, \mathrm{Ser}_{46}, \mathrm{Ser}_{48}, \mathrm{Thr}_{49}$ and $\mathrm{Ser}_{66}, \mathrm{Ser}_{67}, \mathrm{Ser}_{68}, \mathrm{Ser}_{75}$, showed the release of the numerous phosphopeptides accumulating mostly by the end of cheese ripening (e.g., f41/42/46-60, f44/45/46-58, f65-74/79, f67-79; Table 3). We observed an extensive cleavage in these regions of $\alpha_{\mathrm{S}_{1}} \mathrm{CN}$ as expected (Figure 5a). However, we could assign only a few hydrolysis sites to the activity of the particular proteinases: $\mathrm{Lys}_{42}-\mathrm{Asp}_{43}, \mathrm{Lys}_{58}-\mathrm{Gln}_{59}$, and $\mathrm{Lys}_{79}-\mathrm{His}_{80}$ have been reported as possible cleavage sites of plasmin (McSweeney et al., 1993b), and the bond $\mathrm{Asn}_{74}-\mathrm{Ser}_{75}$ has been shown to be cut by CEP of Lc. lactis (Kunji et al., 1996). The successive cutting patterns in the regions f41-49 and f64-72, and f58-62 demonstrated the presence of mainly either the $\mathrm{N}$ terminal or only the C-terminal AA of peptides in the consecutive positions, respectively (Figure 5a). Therefore, we suggested that amino- and carboxypeptidases of LAB could have been likely involved in the formation of peptides from the respective regions. Interestingly, the phosphopeptides only from the narrower region of $\alpha_{\mathrm{S1}}-\mathrm{CN}$, f61-79, have been identified in Grana Padano cheese (Ferranti et al., 1997a).

The central part of $\alpha_{\mathrm{S}^{-}} \mathrm{CN}$, f80-124, was extensively hydrolyzed by different proteolytic enzymes in Old Saare cheese (Figure 5a). Plasmin could have cleaved this region at 7 sites: $\mathrm{Lys}_{79}-\mathrm{His}_{80}, \mathrm{Arg}_{90^{-}}-\mathrm{Tyr}_{91}, \mathrm{Arg}_{100^{-}}$ $\mathrm{Leu}_{101}, \mathrm{Lys}_{102}-\mathrm{Lys}_{103}, \mathrm{Lys}_{103}-\mathrm{Tyr}_{104}, \mathrm{Arg}_{119}-\mathrm{Leu}_{120}$, and Lys $_{124}-\mathrm{Glu}_{125}$ (McSweeney et al., 1993b); chymosin at $\mathrm{Leu}_{98}-\mathrm{Leu}_{99}$ and $\mathrm{Leu}_{101}-\mathrm{Lys}_{102}$ (Exterkate et al., 1997); cathepsin D at $\mathrm{Leu}_{98}-\mathrm{Leu}_{99}$ (Larsen et al., 1996); CEP of lactococci at $\mathrm{Glu}_{84}-\mathrm{Asp}_{85}, \mathrm{Ser}_{88}-\mathrm{Glu}_{89}, \mathrm{Leu}_{98}-\mathrm{Leu}_{99}$, and $\mathrm{His}_{121}$ Ser $_{122}$ (Kunji et al., 1996); CEP of Lb. helveticus at 17 sites (Sadat-Mekmene et al., 2011); and the enzymes of St. thermophilus at 13 sites (Miclo et al., 2012). Besides, the consecutive splitting pattern in the regions f97-101 and f119-124 may indicate a possible involvement of bacterial carboxypeptidases in the proteolysis of the central part of $\alpha_{S 1}-\mathrm{CN}$ (Figure 5a). Thus, the intensive cutting in this region resulted in the formation of abundant peptides $\alpha_{\mathrm{S1}^{-}} \mathrm{CN}$ f85-93, f105-124, and f115-121/122 (Table 3).

We observed a moderate hydrolysis in the regions $\alpha_{S 1}$ CN f131-142 and f180-199 (Figure 4a, Supplemental Figure S1a, https://doi.org/10.3168/jds.2017 -12944) that could be associated with the action of enzymes of mesophilic and thermophilic LAB at the ends of these regions (Kunji et al., 1996; Sadat-Mekmene et al., 2011; Miclo et al., 2012), as well as of chymosin on the bonds $\mathrm{Leu}_{142}-\mathrm{Ala}_{143}$ and $\mathrm{Phe}_{179}{ }^{-} \mathrm{Ser}_{180}$ (McSweeney et al., 1993a). We detected a very low hydrolysis in the region $\alpha_{\mathrm{S}_{1}} \mathrm{CN}$ f145-175 in Old Saare cheese (Figure 4a, Figure 5a, Supplemental Figure S1a, https://doi .org/10.3168/jds.2017-12944), although chymosin has been reported to have potential cleavage sites at $\mathrm{Leu}_{149^{-}}$ $\mathrm{Phe}_{150}, \mathrm{Phe}_{153}-\mathrm{Tyr}_{154}, \mathrm{Leu}_{156}-\mathrm{Asp}_{157}, \mathrm{Tyr}_{159}-\mathrm{Pro}_{160}$, and $\operatorname{Trp}_{164}-\mathrm{Tyr}_{165}$ (McSweeney et al., 1993a) as well as proteolytic enzymes of LAB could have also cut this region based on in vitro studies (Monnet et al., 1992; Sadat-Mekmene et al., 2011; Miclo et al., 2012). Our results were in agreement with the results obtained by Exterkate et al. (1997), who reported that chymosin has failed to cleave bonds in the C-terminal part of $\alpha_{\mathrm{S} 1}-\mathrm{CN}$ f129-199 in Gouda cheese due to the specific structural arrangement of the $\alpha_{S_{1}}-\mathrm{CN}$ molecules in cheese, which could also be a reason for the worse susceptibility of the C-terminus of $\alpha_{S_{1}}$ CN to chymosin and proteolytic enzymes of LAB in Old Saare cheese.

It is worth mentioning that the observed occurrence of several hydrolysis sites of plasmin (Figure 5a), some specific and some overlapping with other proteinases, was an indication of its possible important role in the degradation of $\alpha_{\mathrm{S}_{1}} \mathrm{CN}$ in Old Saare cheese. This conclusion is supported by the fact that the high cooking temperature of curd grains $\left(52^{\circ} \mathrm{C}\right)$ activated the enzyme, and increasing $\mathrm{pH}$ during the ripening of Old Saare cheese (Table 1) became more favorable for plasmin action.

$\alpha_{S 2^{-}} C N-D e r i v e d$ Small Peptides. Lower overall content of water-soluble peptides derived from $\alpha_{\mathrm{S}_{2}} \mathrm{CN}$ was in agreement with a lower abundance of this casein in cheese (Figure 4). Furthermore, a slower release of $\alpha_{S_{2}}$ CN-derived peptides compared with those from other caseins has been presumably associated with its lower accessibility to proteolytic enzymes within casein matrix in cheese (Farrell et al., 2009).

The peptides originating from the N-terminal region f1-24 and released in the result of primary action of plasmin on the preferable bonds $\mathrm{Lys}_{21}-\mathrm{Gln}_{22}$ and $\mathrm{Lys}_{24}-\mathrm{Asn}_{25}$ (Le Bars and Gripon, 1989), comprised only approximately $1 \%$ of all $\alpha_{\mathrm{S} 2}$-CN derived peptides in the 1-d-old cheese and reached the maximum relative content of $10 \%$ in the 4-mo-old cheese. Peptides mainly from the phosphorylated region f6-21, with phosphate groups at $\mathrm{Ser}_{8}, \mathrm{Ser}_{9}, \mathrm{Ser}_{10}, \mathrm{Ser}_{13}, \mathrm{Ser}_{16}$, and $\mathrm{Thr}_{19}$, accumulated to some relatively low amounts in the cheese (Figure 4b). The peptide bond $\mathrm{Glu}_{5}-\mathrm{His}_{6}$ has been shown to be hydrolyzed by CEP of Lb. helveticus (Sadat-Mekmene et al., 2011) and proteolytic system of St. thermophilus (Miclo et al., 2012). Phosphopeptides in the N-terminal $\alpha_{S_{2}}$ CN region (i.e., f7-18/19/21) have been also found in Grana Padano cheese in the study of Ferranti et al. (1997a), where the authors have speculated that carboxypeptidases are involved in the 
production of these peptides. According to our results, the cleavage pattern of the N-terminal region of $\alpha_{\mathrm{S}_{2}} \mathrm{CN}$ may also suggest a possible action of aminopeptidases as well as carboxypeptidases on the respective regions f5-14 and f15-21 (Figure 5b), where notable cleavage occurred at every bond either in the $\mathrm{N}$ - or C-terminal ends of peptides.

We found a very low hydrolysis and a low total amount of peptides released from the region $\alpha_{\mathrm{S}_{2}} \mathrm{CN}$ f25-80 (Figure 4b and Figure 5b). Although the MS/ MS analysis determined some phosphopeptides with phosphorylation at $\mathbf{S e r}_{31}, \mathrm{Ser}_{52}, \mathrm{Ser}_{56}, \mathrm{Ser}_{57}, \mathrm{Ser}_{58}$, $\mathrm{Ser}_{61}$, and $\mathrm{Thr}_{66}$, we did not notice any accumulation of phosphopeptides from this region, unlike in the case with other highly phosphorylated sequences in $\beta-\mathrm{CN}$ and $\alpha_{\mathrm{S}_{1}} \mathrm{CN}$. This revealed that in this region chymosin and plasmin could not release oligopeptides during primary hydrolysis of $\alpha_{S_{2}-} \mathrm{CN}$. The lack of cleavage in this part of the molecule agreed with 3-D model of $\alpha_{\mathrm{S}_{2}} \mathrm{CN}$ developed by Farrell et al. (2009) locating the cleavage sites of proteolytic enzymes mainly in the most surface-accessible portions of the molecule, the relatively hydrophobic and highly positively charged C-terminal half of the protein.

So, the peptides derived from the $\alpha_{\mathrm{S}^{2}} \mathrm{CN}$ determined in our study originated mainly from the C-terminal part of the sequence (Figure 4b). Accordingly, the most prevalent peptides from $\alpha_{\mathrm{S}_{2}}$ CN derived from the following regions: f100-115, f125-142, f150-162, f175-182, and f187-197 (Table 3, Figure 4b). Four phosphopeptides, f128-137/138/140/142, phosphorylated at positions $\mathrm{Ser}_{129}, \mathrm{Thr}_{130}, \mathrm{Ser}_{131}, \mathrm{Ser}_{135}$, and $\mathrm{Thr}_{138}$, accumulated by the end of the ripening and showed high concentrations among other $\alpha_{\mathrm{S}^{2}} \mathrm{CN}$ derived peptides (Table 3). The $\alpha_{\mathrm{S} 2}-\mathrm{CN}$ has been considered to be a good substrate for plasmin (Fox and McSweeney, 1996). Many of the major cleavage sites in the $\alpha_{\mathrm{S}^{2}} \mathrm{CN}$ sequence: $\mathrm{Arg}_{114}-\mathrm{Asn}_{115}$, Lys $_{149}-$ Lys $_{150}$, Lys $_{150}-\mathrm{Thr}_{151}$, Lys $_{188}-$ Asp $_{189}$, Lys $_{197}-\mathrm{Thr}_{198}$ (Figure 5b), involved in the extensive formation of peptides in the C-terminus of the $\alpha_{\mathrm{S}_{2}} \mathrm{CN}$, may be related to plasmin action (Le Bars and Gripon, 1989). However, bacterial proteases could also largely contribute to the splitting of these sites; for example, CEP of $L c$. lactis strains may hydrolyze $\alpha_{\mathrm{S}_{2}}$ CN bonds $\mathrm{Lys}_{150^{-}}-\mathrm{Thr}_{151}$ and $\mathrm{Lys}_{197}-\mathrm{Thr}_{198}$ (Monnet et al., 1992), CEP of Lb. helveticus may hydrolyze the bond $\mathrm{Arg}_{114}-\mathrm{Asn}_{115}$ (SadatMekmene et al., 2011), and enzymes of St. thermophilus may act on all aforementioned plasmin-preferable sites, including $\mathrm{Lys}_{24}-\mathrm{Asn}_{25}$ at the N-terminus, according to in vitro studies (Miclo et al., 2012). In general, $\alpha_{\mathrm{S}^{-}} \mathrm{CN}$ is relatively resistant to chymosin hydrolysis (Fox and McSweeney, 1996) with cleavage sites restricted to the hydrophobic regions of the molecule (McSweeney et al., 1994). According to our data, none of the peptides among most abundant ones (Table 3) could be ascribed to the potential chymosin action except $\alpha_{\mathrm{S}^{2}} \mathrm{CN}$ f175-182, released in the result of cleavage of the bond $\mathrm{Phe}_{174}-\mathrm{Ala}_{175}$ (McSweeney et al., 1994). However, both CEP of lactococci (Monnet et al., 1992) and proteolytic enzymes of streptococci (Miclo et al., 2012) may also compete for this cleavage. It should be noted that the set of major $\alpha_{\mathrm{S}^{2}} \mathrm{CN}$-derived peptides determined in Old Saare cheese differed essentially from the peptides identified in Grana Padano cheese, which have been assumed to originate from chymosin hydrolysis (Ferranti et al., 1997b). Explicitly, the only peptide found in common in these 2 cheeses was $\alpha_{\mathrm{S}_{2}} \mathrm{CN}$ f175-182. The potential cleavage sites of cathepsin $\mathrm{D}$ on $\alpha_{\mathrm{S}^{2}} \mathrm{CN}$ (Larsen et al., 1996) differ from those of chymosin, but coincide with in vitro hydrolysis positions of St. thermophilus proteases (Miclo et al., 2012). Among these sites, we should highlight the cleavage of the bonds $\mathrm{Leu}_{99}-\mathrm{Tyr}_{100}$ and $\mathrm{Thr}_{182}-\mathrm{Val}_{183}$ (may be also cleaved by CEP of lactococci; Monnet et al., 1992), accompanied by the release of corresponding peptides (f100-114/115 and f175/176-182) in noticeable amounts (Table 3, Figure $5 \mathrm{~b}$ ). The involvement of bacterial proteases in the hydrolysis of $\alpha_{\mathrm{S}^{2}} \mathrm{CN}$ was evident during the ripening of Old Saare cheese: the bond $\mathrm{Asn}_{115}-\mathrm{Ala}_{116}$ has been shown potentially cut by $L c$. lactic, Lb. helveticus, as well as St. thermophilus (Monnet et al., 1992; SadatMekmene et al., 2011; Miclo et al., 2012); the extensive cleavage at $\mathrm{Lys}_{137}-\mathrm{Thr}_{138}$ has been shown to be specific to CEP of lactococci (Monnet et al., 1992); the cleavage at $\mathrm{Leu}_{161}-\mathrm{Asn}_{162}$ and $\mathrm{Asn}_{162}-\mathrm{Phe}_{163}$ has been assigned to the action of St. thermophilus (Miclo et al., 2012). We also found a pronounced cleavage at other in vitro indicated potential hydrolysis sites of Lc. lactis and St. thermophilus: $\mathrm{His}_{186}{ }^{-} \mathrm{Gln}_{187}$ and $\mathrm{Tyr}_{203}-\mathrm{Val}_{204}$ (Monnet et al., 1992; Miclo et al., 2012; Figure 5b). The analysis of cleavage sites suggested the action of aminopeptidases on the consecutive bonds in the regions f100-106, f123-128, f151-155, and carboxypeptidases in the region f109-114 in the C-terminus of $\alpha_{\mathrm{S}_{2}} \mathrm{CN}$ (Figure $5 \mathrm{~b}$ ). In addition, we detected remarkable cleavage of the bonds $\mathrm{Gln}_{127}-\mathrm{Leu}_{128}, \mathrm{Leu}_{128}$-Ser $_{129}, \mathrm{Asp}_{140}$-Met ${ }_{141}$, and $\mathrm{Glu}_{142}-\mathrm{Ser}_{143}$ (Figure 5b), but we did not find the proteolytic agents potentially responsible for these sites in the literature.

$\kappa-C N$-Derived Small Peptides. The $\kappa$-CNderived water-soluble peptides were present in Old Saare cheese in relatively low concentrations compared to those derived from other caseins (Figure 4d). Thus, none of the peptides from $\kappa-\mathrm{CN}$ were observed in cheese in the amounts comparable to the most abundant ones originating from the other caseins (Figure 4d, Table 3). Nevertheless, the analysis of cleavage sites allowed us to distinguish some cuttings indicated in the literature. It 
has been noticed that plasmin has very low activity towards $\kappa-C N$ (Fox and McSweeney, 1996). On the other hand, we found all 3 known hydrolysis sites of cathepsin D (Larsen et al., 1996) hydrolyzed in Old Saare cheese: $\mathrm{Leu}_{32}-\mathrm{Ser}_{33}, \mathrm{Leu}_{79}-\mathrm{Ser}_{80}$, as well as Phe 105 -Met 106 coinciding with the primary cleavage site of chymosin causing milk clotting (Figure 5d).

Although most of the GMP is suggested to be lost in the whey (Fox and McSweeney, 1996), our results showed that the water-soluble peptides originating from the GMP, especially $\kappa$-CN f114-169, actually dominated in the cheese among other $\kappa$-CN-derived small peptides at the beginning of ripening. The water-soluble peptides from the C-terminal part of the GMP, $\kappa-C N$ f145-169, were produced intensively in fresh cheese, and then subsequently degraded during the first month of ripening (Figure 4d, Supplemental Figure S1d, https://doi.org/10.3168/jds.2017-12944). The action of CEP of lactococci, splitting the bonds $\mathrm{Glu}_{151}-\mathrm{Val}_{152}, \mathrm{Asn}_{160}-\mathrm{Thr}_{161}, \mathrm{Val}_{162}-\mathrm{Gln}_{163}, \mathrm{Gln}_{163}-\mathrm{Val}_{164}$, $\mathrm{Thr}_{165}-\mathrm{Ser}_{166}$, and $\mathrm{Thr}_{167}-\mathrm{Ala}_{168}$ (Kunji et al., 1996), followed by the action of aminopeptidases on $\kappa$-CN f145-154, could explain the digestion of C-terminal peptides of GMP to FAA during the second half of Old Saare ripening (Supplemental Figure S1d, S2d, https:/ / doi.org/10.3168/jds.2017-12944).

The peptides from the negatively charged N-terminus of para-k-CN, f1-10, accumulated from the beginning of the ripening and prevailed in more ripened cheese (Figure 4d). The concentration of peptides derived from the para-k-CN regions f33-75 and f96-106 appeared to be fluctuating throughout the ripening. During the whole period of ripening, the small peptides derived from the para- $\kappa-\mathrm{CN}$ part of the protein appeared to be produced by the action of CEP of lactococci on the bonds $\mathrm{Asp}_{20}-\mathrm{Lys}_{21}, \mathrm{Leu}_{32}-\mathrm{Ser}_{33}, \mathrm{Asn}_{41}-\mathrm{Tyr}_{42}, \mathrm{Tyr}_{60^{-}}$ $\mathrm{Tyr}_{61}, \mathrm{Ala}_{65}-\mathrm{Ala}_{66}, \mathrm{Ala}_{71}-\mathrm{Gln}_{72}, \mathrm{Gln}_{75}-\mathrm{Trp}_{76}, \mathrm{Leu}_{79}-\mathrm{Ser}_{80}$, $\mathrm{Ala}_{85}-\mathrm{Lys}_{86}, \mathrm{Met}_{95}-\mathrm{Ala}_{96}, \mathrm{Pro}_{99}-\mathrm{His}_{100}$, and $\mathrm{His}_{102}-\mathrm{Leu}_{103}$ (Kunji et al., 1996), supported by the action of some bacterial endopeptidases with subsequent digestion by exopeptidases (Figure 5d).

We could not assign some extensive cleavages, for example, at the bond $\mathrm{Arg}_{10}-\mathrm{Cys}_{11}$ and on fragment f4860 (Figure 5d) of para- $\kappa-\mathrm{CN}$, as well as at the bonds $\mathrm{Asn}_{123^{-}}-\mathrm{Thr}_{124}, \mathrm{Glu}_{137}-\mathrm{Ala}_{138}$, and $\mathrm{Leu}_{146}-\mathrm{Glu}_{147}$, on GMP (Supplemental Figure S2d, https://doi.org/10.3168/ jds.2017-12944) to the activity of proteolytic enzymes found in the previously published literature.

As we saw from our results, the analysis of cleavage sites performed on all identified casein-derived peptides allowed to determine additional significant cleavages which could not be identified in case of performing the analysis only with the data on abundant peptides, even though our list of abundant peptides was broader (169 peptides) than usually taken in consideration in other studies (Gagnaire et al., 2001; Piraino et al., 2007; Sforza et al., 2012). The omission of less abundant peptides from the analysis would provide only limited information on the bonds in casein sequences that have been preferably cut by proteolytic enzymes, and some important cleavages would have been unnoticed.

Clustering Analysis. Because the amount of data obtained from the LC-MS/MS analysis was both massive and complex, we performed the PCA and clustering analysis based on the selection of the most abundant peptides for better understanding and overall assessment of the evolutionary trends in peptide profiles during ripening (Figure 6). The PCA revealed that the most prominent changes in the profiles of water-soluble peptides occurred within the first 5 mo of Old Saare cheese ripening; subsequently, 5- to 8-mo-old cheeses clustered together on the PCA plot (Figure 6a). The first PC explained $37.7 \%$ and the second PC explained $27.5 \%$ of the variance. To follow the differences in characteristic trends of the evolution of peptides, we clustered the abundant peptides included in PCA into 4 groups according to their changing patterns throughout maturation. An overall allocation of the peptide groups on PCA plot was in accordance with the different ripening stages of Old Saare cheese (Figure 6a). The first group of peptides was associated with unripened, up to the 2-wk-old cheeses, the second group related to the 1- to 3-mo-old cheeses, and the third related to the 3 - to 5 -mo-old cheeses. The remaining period of ripening $(6-8 \mathrm{mo})$ was characterized mainly by the peptides from the fourth group. Similar clustering analysis of 57 most abundant peptides was performed using PCA in Parmigiano-Reggiano cheese during 24 mo of ripening (Sforza et al., 2012); each group of peptides was characterized by respective aging time and different composition.

So, in the case of Old Saare, the first group included the peptides exhibiting the highest content in the 1-dold cheese; then, their content mostly dropped abruptly during $2 \mathrm{wk}$, followed by a slower decrease during the next mo of ripening (Figure 6b). Twelve peptides from $\beta-\mathrm{CN}, 7$ peptides from $\alpha_{\mathrm{S}_{1}} \mathrm{CN}$, and 4 peptides from $\alpha_{S_{2}-}$ CN belonged to the group (Table 3). For instance, this group included some longer water-soluble peptides (i.e., $\beta-\mathrm{CN}$ f29-52 and f73-96), easily released at the beginning of the ripening and giving further rise to numerous smaller peptides at the later stages of the ripening (assigned mostly to groups 3 and 2, respectively).

The peptides clustered in the second group (33 from $\beta-\mathrm{CN}, 17$ from $\alpha_{\mathrm{S1}}-\mathrm{CN}$, and none from $\left.\alpha_{\mathrm{S}_{2}}-\mathrm{CN}\right)$ were characterized by rapid increase during the 1 to 3 mo of the ripening, followed by a decrease to the 5 mo of ripening, then leveling off (Figure 6b). This group 


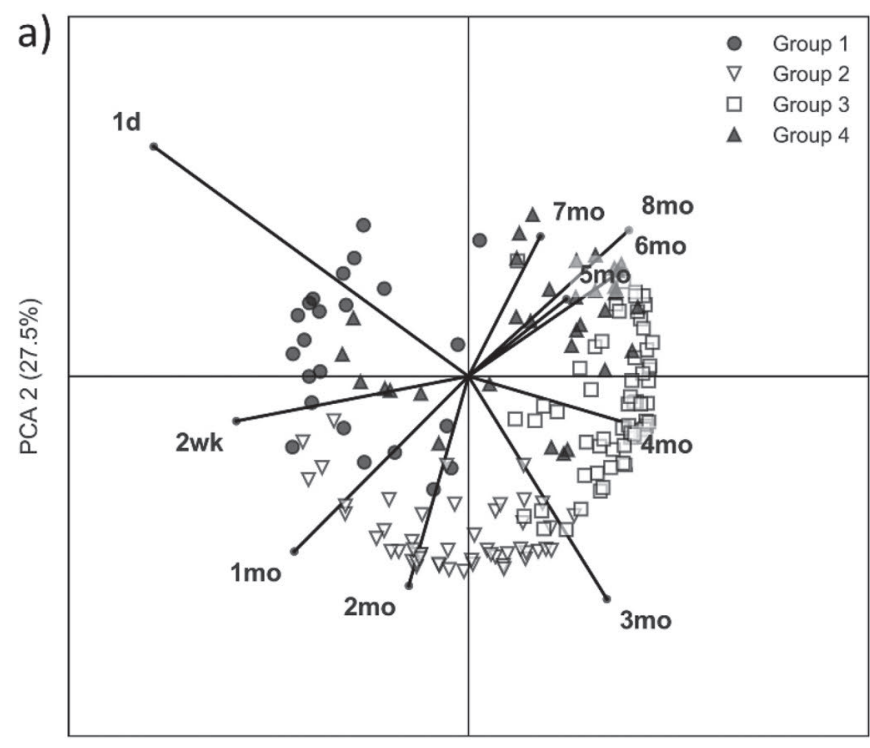

PCA $1(37.7 \%)$
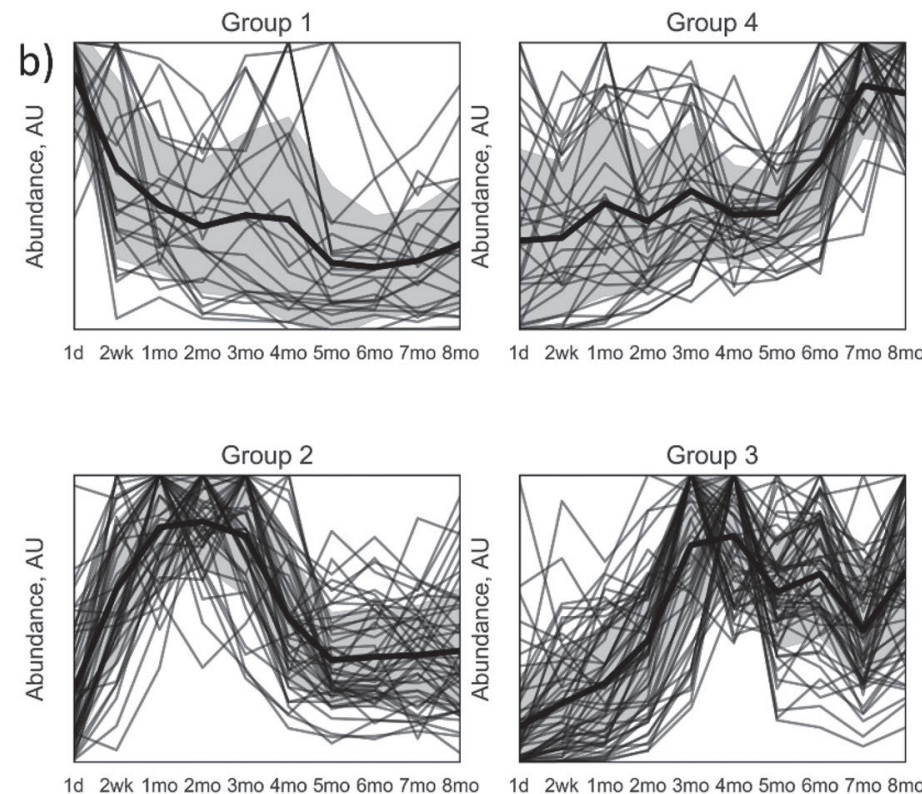

Figure 6. Principal component analysis (PCA; a) and clustering analysis (b) of the most abundant water-soluble peptides determined during Old Saare cheese ripening. Calculations were made using mean values of duplicated samples from each of 2 cheesemaking trials $(\mathrm{n}=4)$. AU $=$ arbitrary units.

consisted of mostly nonphosphorylated peptides; almost all peptides were derived from $\beta-\mathrm{CN}$ region f39-93 and peptides randomly distributed mainly along the N-terminus of $\alpha_{\mathrm{S}_{1}} \mathrm{CN}$ f7-40 (Table 3).

The peptides in the groups 3 and 4 can be largely characterized by accumulating behavior during the ripening. The third group contained the highest number of $\beta$-CN peptides, 42 ; among those are almost all phosphopeptides from region f1-29, two-thirds of the peptides from region f30-52, including most phosphopeptides, and few peptides from the rest of the sequence (Table $3)$. The $\alpha_{S_{1}}-\mathrm{CN}$ and $\alpha_{\mathrm{S}^{-}} \mathrm{CN}$ contributed to the group with 11 and 9 peptides, respectively, again, the majority being potentially phosphorylated. The contents of these peptides increased rapidly at the beginning of the ripening to their maximum value at 3 to $4 \mathrm{mo}$, then slightly decreased by $7 \mathrm{mo}$, followed by another increase in the end of ripening (Figure 6b). Similar to Old Saare, $3 \beta$-CN-derived phosphopeptides, $\beta$-CN f11/12/15-28, were identified in Parmigiano-Reggiano cheese showing the increasing trend and reaching maximum around 5 mo of aging (Sforza et al., 2012). Two accumulating peptides from $\alpha_{\mathrm{S}_{1}}-\mathrm{CN}$ attributed to the third group in Old Saare cheese, $\alpha_{\mathrm{S} 1}$-CN f24-34/36, were also found in Parmigiano-Reggiano, but differently from Old Saare were shown to have maximum values in cheese curd with a constant decrease in amounts during further ripening (Sforza et al., 2012). In Old Saare cheese, the fourth group was formed by 14 peptides from $\beta-\mathrm{CN}$, almost all located in the C-terminal part f106-209; 13 from $\alpha_{\mathrm{S}^{-}}$ $\mathrm{CN}$, a half of them being phosphopeptides from region f44-79; and 7 from $\alpha_{\mathrm{S}_{2}} \mathrm{CN}$, inconsistently distributed along the C-terminal half of the protein (Table 3). A common feature of these peptides was a slight increase in concentration during $5 \mathrm{mo}$ and subsequent notable increase to the maximum value by the end of ripening (Figure 6b). As confirmed by CA, the phosphopeptides, being less available for further digestion by proteolytic agents, accumulated greatly since the middle of cheese ripening. Two peptides from the fourth group, $\beta-\mathrm{CN}$ f194/195-209, were also found in Parmigiano-Reggiano but with different behavior, reaching the maximum values around 1 to 2 mo of ripening and constantly decreasing thereafter (Sforza et al., 2012). According to our results, the PCA and clustering analysis can be easily applied to full data from MS/MS analysis, providing an interesting general characterization of the complex dynamics of peptides during cheese maturation.

\section{Accumulation of FAA}

The content of total FAA increased from $1.2 \pm 0.1$ $\mathrm{g} / \mathrm{kg}$ in the 1 -d-old cheese to $59.9 \pm 1.1 \mathrm{~g} / \mathrm{kg}$ in the 8-mo-old cheese (Table 2). Accumulation was the fastest during the first 4 mo of ripening and slowed down afterward (Figure 1, Table 2).

Figure 7 shows the changes in the relative content of all FAA in the cheese simultaneously at all ripening 
time points and also allows to compare them with AA composition of intact caseins present initially before any hydrolysis in cheese had started (initial intact casein). Thus, the relative content of FAA being higher or lower than in intact caseins allows to determine tentatively either the more preferable cutting regions or the parts of the sequences that have been hydrolyzed to a lesser extent, respectively. The relative content of individual FAA deviated greatly from AA composition of initial intact caseins in the 1-d-old Old Saare cheese (Figure 7). Most but not all FAA stabilized at levels close to their relative molar content in caseins by around 3 to 4 mo (Figure 7). The correlation coefficient between the relative contents of FAA in Old Saare cheese and in initial intact caseins changed from 0.57 in the 1 -d-old cheese to 0.76 in the 8-mo-old cheese. The relative concentration of free Lys was more than 2 times higher in the 1-d-old cheese compared with its content in initial intact casein fraction of Old Saare, and its higher amounts were also maintained during the later stages of the ripening. We explain the intensive production of Lys by the fact that Lys-Lys and Lys-X are the preferable bonds hydrolyzed by plasmin (Fox and McSweeney, 1996), exposing Lys to the action of bacterial exopeptidases. Our results showed that in Old Saare cheese, in addition to $\beta$-CN and $\alpha_{\mathrm{S}^{2}} \mathrm{CN}$, the plasmin was active also in hydrolysis of $\alpha_{\mathrm{S} 1}-\mathrm{CN}$ (Figure 5a), even though it is not the primary target of the enzyme. High production of Lys can be also attributed to the fact that the intracellular enzymes released into the cheese environment during the lysis of bacterial cells can produce much more AA than active bacteria are further able to consume (Ardö et al., 2002). Lactobacillus helveticus was shown to be a most abundant metabolically active species among the other starter bacteria in 1-d-old Old Saare cheese, which abundance decreased during further ripening (L. Blank, TUT, Tallinn, Estonia, personal communication) indicating its potential lysis. Thus, Lb. helveticus could have been actively involved in the release of free Lys. Similarly, Ardö et al. (2002) have found a substantial increase in Lys content in a semi-hard cheese produced with an adjunct culture of $L b$. helveticus. The relative content of free Glu and Arg, which are located at relatively less preferable cleavage sites of plasmin (McSweeney et al., 1993b), was also higher at the beginning of the ripening than in initial intact caseins. The intense conversion of Glu to $\gamma$-aminobutyric acid (GABA) took place during the further ripening by the GABA-producing Glu decarboxylase activity found in St. thermophilus strains (Ardö et al., 2002). We assigned the pronounced decrease in Arg content during the later stages of the ripening (Table 4, Figure 7) to its conversion to the breakdown product Orn and to the production of ATP and carbamyl phosphate, which may be used by cheese microflora for the formation of flavor compounds (Ardö, 2006). Conversely, the relative

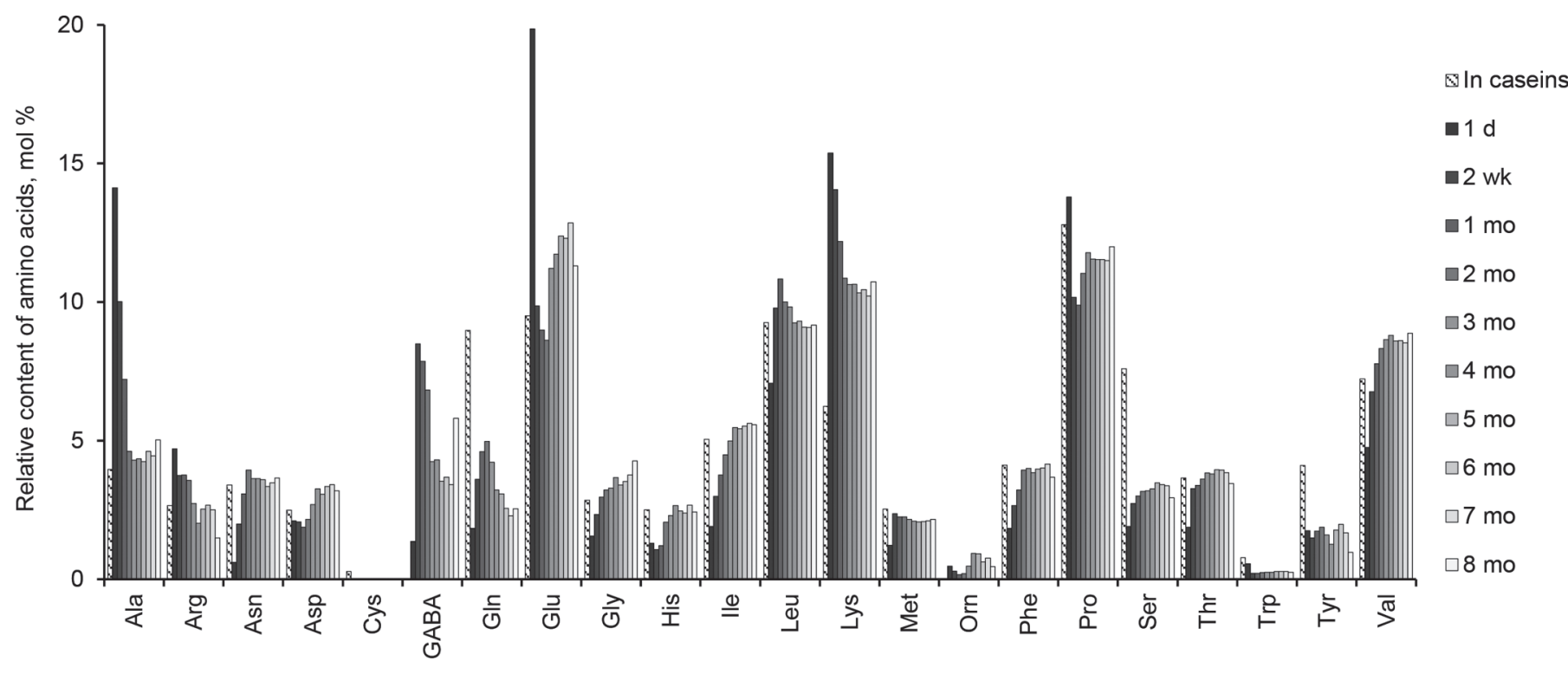

Figure 7. Changes in relative abundance (mol \%) of free AA in Old Saare cheese during the ripening compared to the relative molar AA composition of initial intact caseins before any hydrolysis had started in the cheese (striped bars). The ratios of different caseins for the calculation of the AA composition of initial intact casein were obtained from the data from capillary electrophoresis (CE) of 1-d-old cheese, recalculating the content of the hydrolysis products of $\beta-\mathrm{CN}, \alpha_{\mathrm{S} 1}-\mathrm{CN}$, and $\kappa-\mathrm{CN}\left(\gamma-\mathrm{CN}, \alpha_{\mathrm{S} 1}-\mathrm{I}-\mathrm{CN}\right.$, and para- $\kappa-\mathrm{CN}$, respectively $)$ into the content of the initial unhydrolyzed caseins, which was added to the intact casein fractions ( $\beta-\mathrm{CN}, \alpha_{\mathrm{S}_{1}} \mathrm{CN}$, and $\left.\alpha_{\mathrm{S2}^{2}} \mathrm{CN}\right)$ directly determined by $\mathrm{CE}$ by separate peaks. Results represent the mean values of duplicated samples from each of 2 cheesemaking trials $(n=4)$. 


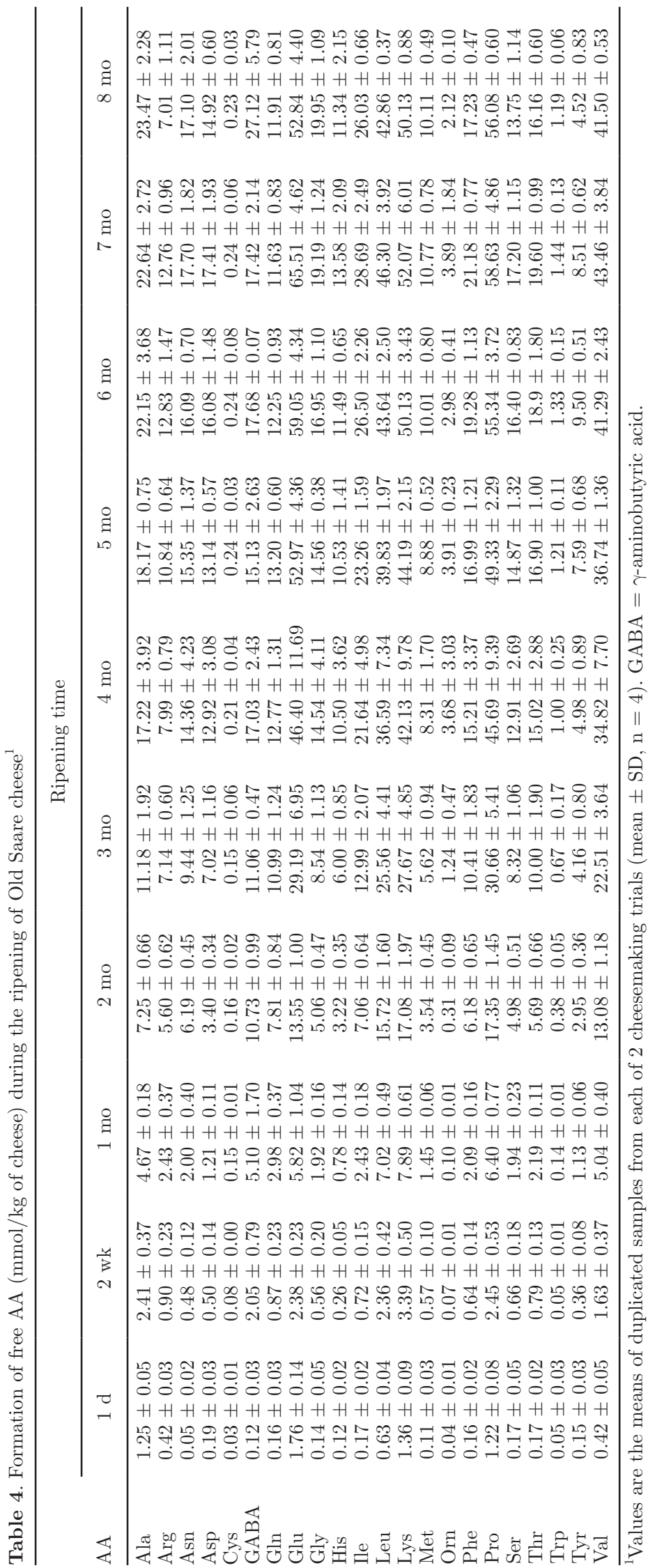


concentration of free Ser was about 2 times lower than could be expected from the AA composition of initial intact caseins. We explained this difference by extensive phosphorylation of Ser in casein sequences indicated by the MS/MS results and significant accumulation of the phosphopeptides, which are not degraded during the cheese ripening. The level of free Gln was lower than expected from the AA composition of initial intact caseins due to its rapid conversion to Glu and GABA.

Proline, Glu, Lys, Leu, and Val (in descending order) were the quantitatively dominating FAA by the end of the ripening in Old Saare cheese (Table 4). We found dissimilarities in the occurrence of dominating FAA and in the order of their relative abundance in the 8-mo ripened Old Saare cheese compared with other cheeses. The content of Pro, present in the highest amounts in Old Saare cheese (Table 4), has been among the less abundant AA in Cheddar, Edam, and Gouda cheeses (Fox and Wallace, 1997) manufactured with mesophilic starter. Additionally, Rehn et al. (2010) found Pro in fifth place among the dominating AA in Västerbottenost cheese, which has also been produced with mesophilic starter using high cooking temperatures. We suggest that the thermophilic starter, used in addition to DL-starter in Old Saare cheese production, may be important in the hydrolysis of Pro-containing peptides by proline-specific peptidases. We should mention that nonstarter lactic acid bacteria, present in cheese as adventitious microflora, may have also been responsible for the degradation of water-soluble peptides and catabolizing of AA to flavor-forming compounds. We did not consider the proteolytic action of nonstarter lactic acid bacteria in a more detail in this study.

\section{CONCLUSIONS}

This work presents the results of the application of different experimental methods and in silico tools that allowed us to carry out the first detailed characterization of the dynamics of different proteinaceous fractions, starting with the degradation of intact caseins followed by the release of peptides of different length and the AA throughout ripening of cheese. The results obtained showed that the majority of the events of casein hydrolysis took place during the first 4 to 5 mo of ripening of Old Saare cheese, suggesting that the cheese may be regarded as practically fully ripened upon expiration of that time. On the other hand, as seen from the further changes in the patterns of cleavage sites, in the dynamics of peptide groups obtained in the clustering analysis, and in the relative abundance of free $\mathrm{AA}$, the ripening events continued until the very end of Old Saare cheese maturation. Application of the high-resolution and high-accuracy LC-MS/MS method allowed determination of a large number $(3,266)$ of small water-soluble peptides. Analysis of cleavage sites based on the detailed LC-MS/MS data proved the necessity of also including the less abundant peptides in the analyses. Important cleavages were assigned to the known specificities of proteolytic agents and new phosphopeptides were detected in the result of the analysis of MS/MS data. More efforts should be undertaken in the future to complete an overall quantitative scheme of proteolysis taking into account also the fractions not fully covered in the present study [i.e., long water-soluble peptides (longer than $25 \mathrm{AA}$ in the sequence) and very short ones (di-, tripeptides)]. The mathematical modeling techniques could and should be applied to the detailed proteolysis data for building models of cheese ripening and exploring the kinetics of production and degradation of peptides.

\section{ACKNOWLEDGMENTS}

Financial support for this work was provided by European Regional Development Fund project EU48667 and by the institutional research funding (IUT19-27) of the Estonian Ministry of Education and Research. We thank Tiiu-Maie Laht (TUT, Tallinn, Estonia) for participation during the initial phase of this project and Saaremaa Dairy Plant (Kuressaare, Estonia) for supplying cheese samples and co-operation. Minna Horst (Varikmaa), Center of Food and Fermentation Technologies (CFFT, Tallinn, Estonia), and Anu Nutt (CFFT) are acknowledged for participation in the project at different stages. We thank Georg Arju (CFFT) and Karl Peebo (CFFT) for fruitful discussions of LCMS/MS analyses. We are also grateful to Signe Adamberg (TUT) for critical reading of the manuscript and helpful suggestions.

\section{REFERENCES}

Akuzawa, R., and P. F. Fox. 2004. Acid phosphatase in cheese. Anim. Sci. J. 75:385-391. https://doi.org/10.1111/j.1740-0929.2004 .00202.x.

Albillos, S. M., M. D. Busto, M. Perez-Mateos, and N. Ortega. 2005. Chemometrical analysis of capillary electrophoresis casein fractions for predicting ripening times of milk mixture cheese. J. Agric. Food Chem. 53:6094-6099. https://doi.org/10.1021/jf050352v.

Albillos, S. M., M. D. Busto, M. Perez-Mateos, and N. Ortega. 2007. Analysis by capillary electrophoresis of the proteolytic activity of a Bacillus subtilis neutral protease on bovine caseins. Int. Dairy J. 17:1195-1200. https://doi.org/10.1016/j.idairyj.2007.02.003.

Ardö, Y. 1999. Evaluating proteolysis by analysing the N content of cheese fraction. In Chemical Methods for Evaluating proteolysis in Cheese Maturation. Part 2. Bull. Int. Dairy Fed. 337:4-10.

Ardö, Y. 2006. Flavour formation by amino acid catabolism. Biotechnol. Adv. 24:238-242. https://doi.org/10.1016/j.biotechadv.2005 .11 .005 .

Ardö, Y., and J. C. Gripon. 1995. Comparative study of peptidolysis in some semi-hard round-eyed cheese varieties with different 
fat contents. J. Dairy Res. 62:543-547. https://doi.org/10.1017/ s0022029900031241.

Ardö, Y., H. Lilbæk, K. R. Kristiansen, M. Zakora, and J. Otte. 2007. Identification of large phosphopeptides from $\beta$-casein that characteristically accumulate during ripening of the semi-hard cheese Herrgård. Int. Dairy J. 17:513-524. https://doi.org/10.1016/j .idairyj.2006.06.027.

Ardö, Y., and A. Polychroniadou. 1999. Laboratory Manual for Chemical Analysis of Cheese. COST 95, Luxembourg. Office for Official Publications of the European Communities, Luxembourg.

Ardö, Y., B. V. Thage, and J. S. Madsen. 2002. Dynamics of free amino acid composition in cheese ripening. Aust. J. Dairy Technol. $57: 109-115$.

Barrett, F. M., A. L. Kelly, P. L. H. McSweeney, and P. F. Fox. 1999 Use of exogenous urokinase to accelerate proteolysis in Cheddar cheese during ripening. Int. Dairy J. 9:421-427. https://doi.org/10 .1016/S0958-6946(99)00047-3.

Broadbent, J. R., M. Barnes, C. Brennand, M. Strickland, K. Houck, M. E. Johnson, and J. L. Steele. 2002. Contribution of Lactococcus lactis cell envelope proteinase specificity to peptide accumulation and bitterness in reduced-fat Cheddar cheese. Appl. Environ. Microbiol. 68:1778-1785.

Callanan, M. J., and R. P. Ross. 2004. Starter cultures: Genetics. Pages 149-161 in Cheese: Chemistry, Physics and Microbiology. Vol. 1. P. F. Fox, P. L. H. McSweeney, T. M. Cogan, and T. P. Guinee, ed. Elsevier Academic Press, London, UK.

Careri, M., S. Spagroli, G. Panari, M. Zannoni, and G. Barbieri. 1996. Chemical parameters of the non-volatile fraction of ripened Parmigiano-Reggiano cheese. Int. Dairy J. 6:147-155. https://doi.org/10 .1016/0958-6946(94)00056-5.

Caroli, A. M., S. Chessa, and G. J. Erhardt. 2009. Invited review: milk protein polymorphisms in cattle: effect on animal breeding and human nutrition. J. Dairy Sci. 92:5335-5352. https://doi.org/10 $.3168 /$ jds.2009-2461.

Cox, J., and M. Mann. 2008. MaxQuant enables high peptide identification rates, individualized p.p.b.-range mass accuracies and proteome-wide protein quantification. Nat. Biotechnol. 26:1367-1372. https://doi.org/10.1038/nbt.1511.

Cox, J., N. Neuhauser, A. Michalski, R. A. Scheltema, J. V. Olsen, and M. Mann. 2011. Andromeda: A peptide search engine integrated into the MaxQuant environment. J. Proteome Res. 10:1794-1805. https://doi.org/10.1021/pr101065j.

Deutsch, S. M., D. Molle, V. Gagnaire, M. Piot, D. Atlan, and S. Lortal. 2000. Hydrolysis of sequenced beta-casein peptides provides new insight into peptidase activity from thermophilic lactic acid bacteria and highlights intrinsic resistance of phosphopeptides. Appl. Environ. Microbiol. 66:5360-5367.

Exterkate, F. A., and A. C. Alting. 1993. The conversion of the $\alpha_{\mathrm{S}_{1}-}$ casein-(1-23)-fragment by the free and bound form of the cellenvelope proteinase of Lactococcus lactis subsp. cremoris under conditions prevailing in cheese. Syst. Appl. Microbiol. 16:1-8.

Exterkate, F. A., F. M. Lagerwerf, J. Haverkamp, and S. van Schalkwijk. 1997. The selectivity of chymosin action on $\alpha_{S 1^{-}}$and $\beta$-caseins in solution is modulated in cheese. Int. Dairy J. 7:47-54. https:// doi.org/10.1016/S0958-6946(96)00047-7.

Farkye, N. Y., and P. F. Fox. 1990. Observations on plasmin activity in cheese. J. Dairy Res. 57:413-418.

Farrell, H. M. Jr., R. Jimenez-Flores, G. T. Bleck, E. M. Brown, J. E. Butler, L. K. Creamer, C. L. Hicks, C. M. Hollar, K. F. Ng-KwaiHang, and H. E. Swaisgood. 2004. Nomenclature of the proteins of cows' milk-Sixth revision. J. Dairy Sci. 87:1641-1674. https://doi .org/10.3168/jds.S0022-0302(04)73319-6.

Farrell, H. M. Jr., E. L. Malin, E. M. Brown, and A. Mora-Gutierrez.

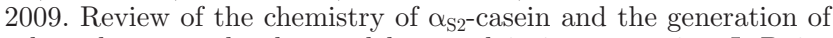
a homologous molecular model to explain its properties. J. Dairy Sci. 92:1338-1353. https://doi.org/10.3168/jds.2008-1711.

Ferranti, P., F. Barone, L. Chianese, F. Addeo, A. Scaloni, L. Pellegrino, and P. Resmini. 1997a. Phosphopeptides from Grana Padano cheese: Nature, origin and changes during ripening. J. Dairy Res. 64:601-615.
Ferranti, P., E. Itolli, F. Barone, A. Malorni, G. Garro, P. Laezza, L. Chianese, F. Migliaccio, V. Stingo, and F. Addeo. 1997b. Combined high resolution chromatographic techniques (FPLC and HPLC) and mass spectrometry-based identification of peptides and proteins in Grana Padano cheese. Lait 77:683-697. https:// doi.org/10.1051/lait:1997649.

Fox, P. F., and P. L. H. McSweeney. 1996. Proteolysis in cheese during ripening. Food Rev. Int. 12:457-509. https://doi.org/10.1080/ 87559129609541091.

Fox, P. F., and J. M. Wallace. 1997. Formation of flavor compounds in cheese. Adv. Appl. Microbiol. 45:17-85.

Gagnaire, V., D. Mollé, M. Herrouin, and J. Léonil. 2001. Peptides identified during Emmental cheese ripening: Origin and proteolytic systems involved. J. Agric. Food Chem. 49:4402-4413.

Gatti, M., J. De Dea Lindner, F. Gardini, G. Mucchetti, D. Bevacqua, M. E. Fornasari, and E. Neviani. 2008. A model to assess lactic acid bacteria aminopeptidase activities in Parmigiano Reggiano cheese during ripening. J. Dairy Sci. 91:4129-4137. https://doi .org/10.3168/jds.2008-1069.

Hayes, M. G., J. C. Oliveira, P. L. H. McSweeney, and A. L. Kelly. 2002. Thermal inactivation of chymosin during cheese manufacture. J. Dairy Res. 69:269-279. https://doi.org/10.1017/ S0022029902005472.

Heck, J. M. L., C. Olieman, A. Schennink, H. J. F. van Valenberg, M. H. P. W. Visker, R. C. R. Meuldijk, and A. C. M. van Hooijdonk. 2008. Estimation of variation in concentration, phosphorylation and genetic polymorphism of milk proteins using capillary zone electrophoresis. Int. Dairy J. 18:548-555. https://doi.org/10.1016/ j.idairyj.2007.11.004.

Holland, J. W., and M. J. Boland. 2014. Post-translational modifications of caseins. Pages 141-168 in Milk Proteins: From Expression Food. H. Singh, A. Thompson, and M. Boland, ed. Elsevier Inc.

Hu, Q., R. J. Noll, H. Li, A. Makarov, M. Hardman, and R. G. Cooks, 2005. The Orbitrap: A new mass spectrometer. J. Mass Spectrom. 40:430-443. https://doi.org/10.1002/jms.856.

Hynek, R., L. Zuzalkova, Z. Sikac, and J. Kas. 2002. Influence of phosphorylation on proteolytic cleavage. J. Liq. Chromatogr. Relat. Technol. 25:2307-2314.

Hynes, E. R., C. V. Bergamini, V. B. Suárez, and C. A. Zalazar. 2003. Proteolysis on Reggianito Argentino cheeses manufactured with natural whey cultures and selected strains of Lactobacillus helveticus. J. Dairy Sci. 86:3831-3840. https://doi.org/10.3168/jds.S0022 -0302(03)73990-3.

ISO (International Organization for Standardization). 2004. Cheese and processed cheese-Determination of the total solids content. ISO 5534. ISO, Geneva, Switzerland.

Jensen, M. P., F. K. Vogensen, and Y. Ardö. 2009. Variation in caseinolytic properties of six cheese related Lactobacillus helveticus strains. Int. Dairy J. 19:661-668. https://doi.org/10.1016/j.idairyj .2009.04.001.

Kaminogawa, S., H. Mizobuchi, and K. Yamauchi. 1972. Comparison of bovine milk protease with plasmin. Agric. Biol. Chem. 36:21632167.

Kunji, E. R., I. Mierau, A. Hagting, B. Poolman, and W. N. Konings. 1996. The proteolytic systems of lactic acid bacteria. Antonie van Leeuwenhoek 70:187-221.

Larsen, L. B., C. Benfeldt, L. K. Rasmussen, and T. E. Petersen. 1996. Bovine milk procathepsin D and cathepsin D: Coagulation and milk protein degradation. J. Dairy Res. 63:119-130. https://doi .org/10.1017/S0022029900031599.

Le Bars, D., and J.-C. Gripon. 1989. Specificity of plasmin towards bovine $\alpha_{\mathrm{S} 2}$-casein. J. Dairy Res. 56:817-821. https://doi.org/10 $.1017 /$ S002202990002940X.

Lund, M., and Y. Ardö. 2004. Purification and identification of watersoluble phosphopeptides from cheese using Fe(III) affinity chromatography and mass spectrometry. J. Agric. Food Chem. 52:66166622. https://doi.org/10.1021/jf0401064.

Maubois, J.-L., and D. Lorient. 2016. Dairy proteins and soy proteins in infant foods nitrogen-to-protein conversion factors. Dairy Sci. Technol. 96:15-25. https://doi.org/10.1007/s13594-015-0271-0. 
McSweeney, P. L. H., N. F. Olson, P. F. Fox, and A. Healy. 1994. Proteolysis of bovine $\alpha_{\mathrm{S} 2}$-casein by chymosin. Z. Lebensm. Unters. Forsch. 199:429-432.

McSweeney, P. L. H., N. F. Olson, P. F. Fox, A. Healy, and P. Højrup. 1993a. Proteolytic specificity of chymosin on bovine $\alpha_{\mathrm{s1}}$-casein. J. Dairy Res. 60:401-412. https://doi.org/10.1017/ S0022029900027734.

McSweeney, P. L. H., N. F. Olson, P. F. Fox, A. Healy, and P. Højrup. 1993b. Proteolytic specificity of plasmin on bovine $\alpha_{\mathrm{s} 1}$-casein. Food Biotechnol. 7:143-158.

Miclo, L., E. Roux, M. Genay, E. Brusseaux, C. Poirson, N. Jameh, C. Perrin, and A. Dary. 2012. Variability of hydrolysis of $\beta-, \alpha_{\mathrm{S1}^{-}}$, and $\alpha_{\mathrm{S}_{2}}$-caseins by 10 strains of Streptococcus thermophilus and resulting bioactive peptides. J. Agric. Food Chem. 60:554-565. https:// doi.org/10.1021/jf202176d.

Milesi, M. M., C. V. Bergamini, and E. Hynes. 2011. Production of peptides and free amino acids in a sterile extract describes peptidolysis in hard-cooked cheeses. Food Res. Int. 44:765-773. https:// doi.org/10.1016/j.foodres.2011.01.007.

Miralles, B., M. Ramos, and L. Amigo. 2003. Influence of proteolysis of milk on the whey protein to total protein ratio as determined by capillary electrophoresis. J. Dairy Sci. 86:2813-2817. https:// doi.org/10.3168/jds.S0022-0302(03)73878-8.

Monnet, V., J. P. Ley, and S. Gonzalez. 1992. Substrate specificity of the cell envelope-located proteinase of Lactococcus lactis subsp. lactis NCDO 763. Int. Biochem. 24:707-718. https://doi.org/10 .1016/0020-711X(92)90004-K.

Otte, J., M. Zakora, K. R. Kristiansen, and K. B. Qvist. 1997. Analysis of bovine caseins and primary hydrolysis products in cheese by capillary zone electrophoresis. Lait 77:241-257.

Piraino, P., V. K. Upadhyay, R. Rossano, P. Riccio, E. Parente, A. L. Kelly, and P. L. H. McSweeney. 2007. Use of mass spectrometry to characterize proteolysis in cheese. Food Chem. 101:964-972. https://doi.org/10.1016/j.foodchem.2006.02.048.

Rappsilber, J., M. Mann, and Y. Ishihama. 2007. Protocol for micropurification, enrichment, pre-fractionation and storage of peptides for proteomics using StageTips. Nat. Protoc. 2:1896-1906. https:// doi.org/10.1038/nprot.2007.261.

Rehn, U., M. A. Petersen, K. Hallin Saedén, and Y. Ardö. 2010. Ripening of extra-hard cheese made with mesophilic DL-starter. Int Dairy J. 20:844-851. https://doi.org/10.1016/j.idairyj.2010.06 .001 .

Rodriguez-Nogales, J. M., and F. Vázquez. 2007. Application of electrophoretic and chemometric analysis to predict the bovine, ovine and caprine milk percentages in Panela cheese, an unripened cheese. Food Contr. 18:580-586. https://doi.org/10.1016/j foodcont.2006.02.003.
Sadat-Mekmene, L., J. Jardin, C. Corre, D. Mollé, R. Richoux, M.-M. Delage, S. Lortal, and V. Gagnaire. 2011. Simultaneous presence of $\mathrm{PrtH}$ and PrtH2 proteinases in Lactobacillus helveticus strains improves breakdown of the pure $\alpha_{\mathrm{S} 1}$-casein. Appl. Environ. Microbiol. 77:179-186. https://doi.org/10.1128/AEM.01466-10.

Sadat-Mekmene, L., R. Richoux, L. Aubert-Frogerais, M.-N. Madec, C. Corre, M. Piot, J. Jardin, S. Le Feunten, S. Lortal, and V. Gagnaire. 2013. Lactobacillus helveticus as a tool to change proteolysis and functionality in Swiss-type cheeses. J. Dairy Sci. 96:1455-1470. https://doi.org/10.3168/jds.2012-6179.

Sánchez-Rivera, L., I. Diezhandino, J. Á. Gómez-Ruiz, J. M. Fresno, B. Miralles, and I. Recio. 2014. Peptidomic study of Spanish blue cheese (Valdeón) and changes after simulated gastrointestinal digestion. Electrophoresis 35:1627-1636.

Scolari, G., M. Vescovo, C. Zacconi, and F. Vescovi. 2006. Extraction and partial characterization of proteolytic activities from the cell surface of Lactobacillus helveticus Zuc2. J. Dairy Sci. 89:38003809. https://doi.org/10.3168/jds.S0022-0302(06)72421-3.

Sforza, S., V. Cavatorta, F. Lambertini, G. Galaverna, A. Dossena, and R. Marchelli. 2012. Cheese peptidomics: A detailed study on the evolution of the oligopeptide fraction in Parmigiano-Reggiano cheese from curd to 24 months of aging. J. Dairy Sci. 95:35143526. https://doi.org/10.3168/jds.2011-5046.

Sheehan, J. J., J. C. Oliveira, A. L. Kelly, and P. L. H. McSweeney. 2007. Effect of cook temperature on primary proteolysis and predicted residual chymosin activity of a semi-hard cheese manufactured using thermophilic cultures. Int. Dairy J. 17:826-834 https://doi.org/10.1016/j.idairyj.2006.08.012.

Sousa, M. J., Y. Ardö, and P. L. H. McSweeney. 2001. Advances in the study of proteolysis during cheese ripening. Int. Dairy J. 11:327345. https://doi.org/10.1016/S0958-6946(01)00062-0.

Tan, P. S. T., B. Poolman, and W. N. Konings. 1993. Proteolytic enzymes of Lactococcus lactis. J. Dairy Res. 60:269-286.

Toelstede, S., and T. Hofmann. 2008. Sensomics mapping and identification of the key bitter metabolites in Gouda cheese. J. Agric. Food Chem. 56:2795-2804.

Upadhyay, V. K., P. L. H. McSweeney, A. A. A. Magboul, and P. F. Fox. 2004. Proteolysis in cheese during ripening. Pages 391-433 in Cheese: Chemistry, Physics and Microbiology. Volume 1. P. F. Fox, P. L. H. McSweeney, T. M. Cogan, and T. P. Guinee, ed. Elsevier Academic Press, London, UK.

Wilkinson, M. G., and K. N. Kilcawley. 2005. Mechanisms of incorporation and release of enzymes into cheese during ripening. Int Dairy J. 15:817-830. https://doi.org/10.1016/j.idairyj.2004.08 .021 . 